\title{
Boomjuridischtijdschriften
}

\section{Totstandkoming, systeem en doelen van de Omgevingswet}

\author{
Mr. dr. H.A. (Harald) Oldenziel en Mr. H.W. (Wilco) de Vos
}

\author{
Aanbevolen citeerwijze bij dit artikel \\ Mr. dr. H.A. (Harald) Oldenziel en Mr. H.W. (Wilco) de Vos, 'Totstandkoming, systeem \\ en doelen van de Omgevingswet', TO 2018-3, p.
}

\section{Stelselherziening van het omgevingsrecht}

\subsection{Inleiding}

Het omgevingsrecht wordt de komende jaren ingrijpend vernieuwd. Onder de noemer 'de stelselherziening van het omgevingsrecht' is enkele jaren geleden een omvangrijk wetgevingstraject gestart. Daarmee komt een groot deel van de regels over de fysieke leefomgeving samen in één nieuw stelsel. Het nieuwe omgevingsrecht wordt geregeld in de Omgevingswet (Ow), de vier daarop gebaseerde algemene maatregelen van bestuur ${ }^{\mathbf{1}}$ (AMvB's) en de Omgevingsregeling.

Voor een goed begrip van het nieuwe wettelijke stelsel is het van belang om inzicht te hebben in de totstandkoming, het systeem en de doelen van de Omgevingswet. Deze bijdrage is daarop gericht. ${ }^{2}$ Deze bijdrage zal een plaats krijgen in het Handboek Omgevingswet dat in voorbereiding is.

In dit hoofdstuk worden de aanleiding, de verbeterdoelen, het totstandkomingsproces en de verschillende onderdelen van de stelselherziening beschreven. In hoofdstuk 2 komen het systeem, het toepassingsgebied en de doelen van de nieuwe wetgeving aan de orde.

\subsection{Aanleiding voor de stelselherziening}

De bestaande regels over de fysieke leefomgeving zijn verspreid over een groot aantal wetten, AMvB's, ministeriële regelingen en regelingen van gemeenten, waterschappen en provincies. De variëteit daarbinnen is groot. Het loopt uiteen van algemene wetten met procedureregels tot specifieke regelingen met gedetailleerde technische voorschriften. Ook de regels in de naar schatting 50.000 bestaande bestemmingsplannen behoren tot het omgevingsrecht. De verschillende bestaande regels zijn niet als stelsel ontworpen, maar het resultaat van een langjarige ontwikkeling. Ze zijn stapsgewijs tot stand gekomen naar aanleiding van de maatschappelijke behoefte aan regels over 
diverse onderwerpen, zoals het voorkomen van overstromingen of het tegengaan van lucht-, water- en bodemvervuiling. Een aanzienlijk deel van die regels is in Europees of internationaal verband ontstaan. Zo ontstond in de loop van de jaren een verzameling van regels, gericht op specifieke activiteiten of onderdelen van de fysieke leefomgeving.

Een gevolg van het organische groeiproces van het omgevingsrecht is dat de interne coherentie binnen de bestaande regels beperkt is. De huidige sectorale regels kennen verschillen in systematiek, instrumenten en terminologie. Ook bevatten ze verschillende regimes voor afstemming. Dat maakt de toepassing complex. De wens om te komen tot vereenvoudigde en samenhangende regels op het gebied van het omgevingsrecht vormt dan ook de belangrijkste aanleiding voor de stelselherziening. De politieke aanleiding voor de stelselherziening is terug te voeren op de motie-Pieper van eind 2009. ${ }^{3}$ Die motie beklemtoonde de complexiteit van het bestaande recht en riep de regering op om voorstellen te doen voor een fundamentele herziening van het omgevingsrecht. Het onderwerp heeft uiteindelijk een plek gekregen in de regeerakkoorden van de kabinetten Rutte I, II en III. 4

De wens tot het bevorderen van samenhang kent ook een inhoudelijke component. In de loop van de tijd is er meer aandacht gekomen voor samenhangende opgaven in de fysieke leefomgeving, zoals het behoud van biodiversiteit en klimaatadaptatie. Ook is er vaak samenloop van regels bij complexere projecten en de ontwikkeling van gebieden. In de praktijk zijn de diverse activiteiten en onderdelen van de fysieke leefomgeving op elkaar van invloed. Zo kan de aanleg van een weg niet los worden gezien van de omgeving; denk aan de gevolgen voor geluid, lucht en natuur. Omgekeerd heeft milieu- of natuurbescherming gevolgen voor het benutten van de fysieke leefomgeving voor andere doeleinden, zoals landbouw, industrie of recreatie. De wisselwerking tussen (onderdelen van) de fysieke leefomgeving en de daarin voorkomende activiteiten bepaalt mede de kwaliteit van de fysieke leefomgeving in een bepaald gebied.

In veel gebieden in Nederland is de ruimte beperkt en zijn er uiteenlopende wensen en maatschappelijke behoeften. Dit zorgt voor verdelingsvraagstukken. Welke ruimte is er voor landbouw, industrie, verkeer, vervoer, wonen, natuur, (wereld)erfgoed enz.? Welke waarborgen zijn er voor een goed leefklimaat voor mensen, flora en fauna? Het bereiken van een goede kwaliteit van de fysieke leefomgeving vraagt om samenhangende keuzes en een efficiënte verdeling van de beschikbare fysieke ruimte en de milieugebruiksruimte. Het recht dient daarvoor de juridische randvoorwaarden en instrumenten te bieden.

Enkele bestaande wetten, zoals de Wet ruimtelijke ordening, de Wet milieubeheer en de Waterwet, voorzien in een samenhangende regeling op deelterreinen. Op die terreinen zijn in de loop van de jaren de regels in belangrijke mate geïntegreerd. Ook zijn er wetten die voor bepaalde onderwerpen een brede regeling bieden, zoals de Wet algemene bepalingen omgevingsrecht voor vergunningverlening en bestuursrechtelijke handhaving. Een overkoepelend wettelijk kader, dat een samenhangende benadering van de fysieke leefomgeving stimuleert, ontbrak tot nu toe. De Omgevingswet voorziet daarin. Het nieuwe wettelijke stelsel bouwt daarmee voort op de al gerealiseerde integratie binnen onderdelen van het omgevingsrecht. 


\subsection{Verbeterdoelen van de stelselherziening}

Het nieuwe stelsel beoogt te voorzien in overzichtelijke en samenhangende regels voor een duurzame ontwikkeling van de fysieke leefomgeving. Het stelsel dient de instrumenten en de flexibiliteit te bieden om maatschappelijke opgaven te verwezenlijken. Ook moet het stelsel tijdig uitvoering kunnen geven aan internationaalrechtelijke verplichtingen. De stelselherziening van het omgevingsrecht heeft vier verbeterdoelen:

- het vergroten van de inzichtelijkheid, de voorspelbaarheid en het gebruiksgemak van het omgevingsrecht;

- het bewerkstelligen van een samenhangende benadering van de fysieke leefomgeving in beleid, besluitvorming en regelgeving;

- het vergroten van de bestuurlijke afwegingsruimte door een actieve en flexibele aanpak mogelijk te maken voor het bereiken van doelen voor de fysieke leefomgeving;

- het versnellen en verbeteren van besluitvorming over projecten in de fysieke leefomgeving. 5

Deze beleidsmatige verbeterdoelen zijn opgenomen in de memorie van toelichting bij de Omgevingswet. ${ }^{6}$ Ze vormen het ijkpunt voor de gehele stelselherziening. De verbeterdoelen werken in de eerste plaats direct door in de vormgeving van de regelgeving. Zo wordt de inzichtelijkheid vergroot door een heldere structuur binnen de nieuwe omgevingsrechtelijke regelgeving en door het harmoniseren van instrumenten en terminologie. Hierop wordt in hoofdstuk 2 ingegaan. Daarnaast zullen de verbeterdoelen gestalte moeten krijgen in beleid, besluitvorming en de uitvoeringspraktijk. Dit vraagt onder meer om veranderingen in aanpak, (bestuurs)cultuur, samenwerking en het vergroten van kennis en kunde. Belangrijk is ook de bredere toepassing van ICT, voor het digitaal kunnen doen van aanvragen of meldingen en voor het ontsluiten van regels en beschikbare gegevens over (onderdelen van) de fysieke leefomgeving. ${ }^{7}$

\subsection{Totstandkomingsproces}

Een stelselherziening van een grote omvang ontstaat niet van de ene op de andere dag. De totstandkoming is een meerjarig traject dat uit verschillende stappen bestaat. De onderdelen waaruit het nieuwe stelsel is opgebouwd, worden in paragraaf 1.5 besproken. In deze paragraaf wordt kort aandacht besteed aan de vele betrokkenen en het verloop van het totstandkomingsproces.

Het omgevingsrecht wordt gekenmerkt door een groot aantal betrokken belangen en belanghebbenden. In de fysieke leefomgeving zijn veel partijen aanwezig, denk aan overheden, bedrijven, bewoners en belangenorganisaties. Activiteiten van de een kunnen gevolgen hebben voor de belangen van de ander. Verder is relevant dat de zorg voor de onderdelen van de fysieke leefomgeving, zoals infrastructuur, milieu, natuur, bouwwerken en monumenten, bij diverse overheidslagen en bestuursorganen is belegd. Verder is een kenmerk dat het omgevingsrecht zeer omvangrijk is en vele technische 
normen bevat. Voor een goede kwaliteit van de regelgeving is expertise, kennis en ervaring op diverse terreinen noodzakelijk. De vernieuwing van het omgevingsrecht is dan ook al vroeg in het beleidsproces aangemerkt als een kabinetsbrede ambitie die een intensief samenspel vereist met decentrale overheden, maatschappelijke organisaties, wetenschap en praktijk. ${ }^{\mathbf{8}} \mathrm{Om}$ een bestendig, kwalitatief goed en breed gedragen stelsel te verkrijgen, kent de stelselherziening een totstandkomingsproces met een brede betrokkenheid van diverse partijen.

In paragraaf 1.2 is de politieke aanleiding van de stelselherziening toegelicht. Hieronder worden enkele momenten uit het totstandkomingsproces gelicht die van betekenis zijn geweest voor de vormgeving van de stelselherziening. De eerste stap was dat in 2010 diverse deskundigen uit wetenschap en praktijk zijn gevaagd om een essay te schrijven over de toekomst van het omgevingsrecht. Deze essays zijn opgenomen in een door het toenmalige ministerie van Infrastructuur en Milieu uitgebrachte bundel Bezinning op het omgevingsrecht. ${ }^{9}$ Hierna volgde een fase van beleidsverkenning, overleg met diverse betrokkenen en in 2011 de eerste brieven over de voorgenomen stelselherziening aan de Tweede Kamer. ${ }^{\mathbf{1 0}}$ Aangezien de stelselherziening een belangrijk en omvangrijk wetgevingsproject betreft, is over het beleidsvoornemen in 2011 voorlichting gevraagd aan de Afdeling advisering van de Raad van State. ${ }^{\mathbf{1 1}}$ Het resultaat van het beleidsproces is opgenomen in een uitgebreide beleidsbrief van maart 2012. ${ }^{\mathbf{1 2}}$ Daarover heeft een openbare internetconsultatie plaatsgevonden, gevolgd door een algemeen overleg in de Tweede Kamer.

De beleidsbrief was vooral van betekenis voor het bepalen van de doelen en uitgangspunten van de stelselherziening. Op basis daarvan is begin 2013 een eerste voorontwerp voor de Omgevingswet opgesteld dat door verschillende partijen is getoetst of van een reactie is voorzien. Het resultaat daarvan is verwerkt in een wetsvoorstel voor een nieuwe Omgevingswet dat in juli 2013 voor advies aan de Afdeling advisering van de Raad van State is voorgelegd. Hierop volgde een uitgebreid en op onderdelen kritisch advies. ${ }^{\mathbf{1 3}}$ Het advies was tegelijkertijd ook opbouwend. De Afdeling onderkende de behoefte aan samenhangende besluitvorming en vereenvoudiging van het omgevingsrecht. Belangrijke thema's in het advies waren de sturing van de wet op de kwaliteit van de fysieke leefomgeving, de balans tussen flexibiliteit en rechtszekerheid en de verantwoordelijkheidsverdeling tussen overheden. Het advies heeft tot enkele belangrijke aanvullingen en wijzigingen van het wetsvoorstel geleid. In het bijzonder werd het wetsvoorstel voorzien van diverse procedurele en inhoudelijke waarborgen. Daarnaast was voor het vervolg van het proces van de stelselherziening van belang dat de Afdeling in haar advies aangaf de uitvoeringsregelgeving (de ontwerp-AMvB's) en het wetsvoorstel Invoeringswet Omgevingswet (hierna: Invoeringswet) in samenhang te willen beoordelen. Dit is ook gebeurd.

In juni 2014 heeft de regering het wetsvoorstel Omgevingswet ingediend bij de Tweede Kamer. ${ }^{\mathbf{1 4}}$ De brede maatschappelijke betrokkenheid werd door de Kamer voortgezet door middel van twee rondetafelbijeenkomsten, waarbij diverse partijen uit het veld en de wetenschap werden uitgenodigd. Verder heeft de Kamer de Rijksuniversiteit Groningen opdracht gegeven om onderzoek te doen naar de verwerking van het advies van de Afdeling advisering van de Raad van State. ${ }^{\mathbf{1 5}}$ De rondetafelbijeenkomsten en het onderzoek zijn 
belangrijke input geweest voor het verslag en nader verslag. Daarin kregen, naast de onderwerpen uit het advies van de Afdeling advisering van de Raad van State, thema's als gezondheid, participatie bij besluitvorming, de borging van specifieke belangen, zoals de toegankelijkheid voor gehandicapten, de bescherming van werelderfgoed en klimaat, en ICT veel aandacht. Dit kwam tijdens de mondelinge behandeling onder meer tot uitdrukking in diverse amendementen afkomstig van verschillende Kamerleden. In totaal zijn 38 amendementen en 23 moties aangenomen. Ook de behandeling in de Eerste Kamer werd gekenmerkt door meerdere schriftelijke vragenrondes, deskundigenbijeenkomsten en een uitvoerige mondelinge behandeling. Dit uitgebreide parlementaire proces heeft bijgedragen aan een breed draagvlak in het parlement voor de Omgevingswet. Het wetsvoorstel is in de Tweede Kamer (juli 2015) en de Eerste Kamer (maart 2016) met een grote meerderheid aangenomen.$^{\mathbf{1 6}}$ Het voorstel is vervolgens bekrachtigd, waarna de wet in april 2016 in het Staatsblad is gepubliceerd. ${ }^{\mathbf{1 7}}$

Ook de op de Omgevingswet gebaseerde AMvB's kennen een uitgebreid totstandkomingsproces met brede maatschappelijke betrokkenheid. De ontwerp-AMvB's zijn in juli 2016 openbaar geconsulteerd en vervolgens na rondetafelbijeenkomsten en schriftelijke vragenrondes in december 2016 in de Tweede Kamer en in mei 2017 in de Eerste Kamer besproken in het kader van de zogenoemde voorhangprocedure. De AMvB's bevatten een belangrijk deel van de inhoudelijke regels over (activiteiten in) de fysieke leefomgeving. Belangrijke algemene thema's in het maatschappelijke en politieke debat waren bestuurlijke afwegingsruimte en participatie. Ook was er veel aandacht voor de totstandkoming van het digitale stelsel en een goede implementatie van de stelselherziening. Tijdens de debatten in de Tweede en Eerste Kamer bleek er politieke steun voor de voorgenomen opzet van de uitwerking van de AMvB's. De uitkomsten zijn vervolgens verwerkt in de vier ontwerpbesluiten die in juli 2017, tezamen met het voorstel voor de Invoeringswet, aan de Afdeling advisering van de Raad van State zijn voorgelegd. De Afdeling heeft daarop een advies uitgebracht met een positief dictum. Na verwerking daarvan zijn de AMvB's in juli 2018 vastgesteld en vervolgens in het Staatsblad gepubliceerd. ${ }^{\mathbf{1 8}}$

Het hierboven beschreven proces zal ook worden gevolgd bij de meeste wijzigingen of aanvullingen van de Omgevingswet of de AMvB's. Dit is onder meer het geval bij de voorbereiding van de invoerings- en aanvullingsregelgeving (zie paragraaf 1.5.1). Belangrijke onderdelen van het proces zijn ook verankerd in de Omgevingswet. Zo is de consultatie van het publiek bij toekomstige wijzigingen van de AMvB's voorgeschreven in de Omgevingswet (artikel 23.4 Ow). Via een amendement is ook de parlementaire betrokkenheid bij de AMvB's via een zogenoemde voorhangprocedure geborgd (artikel 23.5 Ow). Het brede totstandkomingsproces geldt daarmee dus ook voor de toekomstige ontwikkeling van het stelsel.

\subsection{Onderdelen van de stelselherziening}

\subsubsection{Opbouw van het nieuwe stelsel}

Gezien de omvang van de omgevingsrechtelijke regelgeving is de stelselherziening van het omgevingsrecht niet in één keer te realiseren; fasering is onvermijdelijk. Dit vloeit ook voort uit de voorlichting van de Afdeling advisering van de Raad van State over de stelselherziening van het 
omgevingsrecht. ${ }^{19}$ Daarom werkt de wetgever langs drie sporen aan de totstandkoming van een nieuw stelsel: het hoofdspoor, het invoeringsspoor en de aanvullingssporen. Deze drie sporen zijn in onderstaande tabel schematisch weergegeven. De onderdelen daarvan worden in de paragrafen 1.5.2 tot en met 1.5 .5 kort geduid.

\begin{tabular}{|l|l|l|}
\hline Hoofdspoor & Invoeringsspoor & Aanvullingssporen \\
\hline Omgevingswet & Invoeringswet & $\begin{array}{l}\text { Aanvullingswetten bodem, } \\
\text { geluid, natuur en } \\
\text { grondeigendom }\end{array}$ \\
\hline $\begin{array}{l}\text { Besluit kwaliteit } \\
\text { leefomgeving } \\
\text { Besluit activiteiten } \\
\text { leefomgeving } \\
\begin{array}{l}\text { Besluit } \\
\text { bouwwerken } \\
\text { leefomgeving }\end{array}\end{array}$ & Invoeringsbesluit & $\begin{array}{l}\text { Aanvullingsbesluiten bodem, } \\
\text { geluid, natuur, } \\
\text { grondeigendom en zwemmen } \\
\text { of baden in waterbassins }\end{array}$ \\
\hline $\begin{array}{l}\text { Omgevingsbesluit } \\
\text { Omgevingsregeling }\end{array}$ & Invoeringsregeling & $\begin{array}{l}\text { Aanvullingsregelingen bodem, } \\
\text { geluid, natuur en } \\
\text { grondeigendom }\end{array}$ \\
\hline
\end{tabular}

* De ontwerpen van het Aanvullingsbesluit bodem Omgevingswet en het Aanvullingsbesluit zwemmen of baden in waterbassins Omgevingswet zijn te raadplegen op www.internetconsultatie.nl. De andere aanvullingsbesluiten zijn op moment van schrijven in voorbereiding.

De kern van het nieuwe stelsel wordt gevormd door het hoofdspoor dat in de eerste kolom is weergegeven: de Omgevingswet, de vier AMvB's en de Omgevingsregeling. Die vormen samen het nieuwe stelsel, dat naar verwachting op 1 januari 2021 in werking treedt. De invoeringsregelgeving en de aanvullingsregelgeving bestaan grotendeels uit wijzigingen van of aanvullingen op het hoofdspoor. De invoeringsregelgeving bevat wijzigingen en het overgangsrecht die noodzakelijk zijn om het stelsel in werking te laten treden. De aanvullingsregelgeving bevat aanvullingen met regels over bepaalde onderwerpen. De aanvullingsregelgeving gaat meestal gepaard met beleidsinhoudelijke wijzigingen en volgt om die reden een afzonderlijk spoor. Zie voor een nadere uitleg de paragrafen 1.5.4 en 1.5.5.

Bij inwerkingtreding gaan de wijzigingen en aanvullingen die in het invoeringsspoor en de aanvullingssporen zijn opgenomen op in de verschillende producten van het hoofdspoor (de Omgevingswet, de vier AMvB's en de Omgevingsregeling). De invoeringsregelgeving en de aanvullingsregelgeving houden voor die delen dus geen zelfstandige blijvende betekenis. Zij blijven nog wel tijdelijk van betekenis voor het daarin opgenomen overgangsrecht. 


\subsubsection{Omgevingswet}

De Omgevingswet bevat het juridische instrumentarium, procedures en grondslagen voor regels over (activiteiten in) de fysieke leefomgeving. In paragraaf 2.2 zal nader worden ingegaan op de reikwijdte van de wet. De Omgevingswet bevat regels over zowel het beschermen als het benutten van de fysieke leefomgeving. De nieuwe wet vervangt daarmee een groot aantal bestaande wetten. De volgende wetten zullen via de Invoeringswet worden ingetrokken:

- de Belemmeringenwet Landsverdediging;

- de Belemmeringenwet Privaatrecht;

- de Crisis- en herstelwet;

- de Interimwet stad-en-milieubenadering;

- de Ontgrondingenwet;

- de Planwet verkeer en vervoer;

- de Spoedwet wegverbreding;

- de Tracéwet;

- de Wet algemene bepalingen omgevingsrecht;

- de Wet ammoniak en veehouderij;

- de Wet geurhinder en veehouderij;

- de Wet hygiëne en veiligheid badinrichtingen en zwemgelegenheden;

- de Wet inzake de luchtverontreiniging;

- de Wet ruimtelijke ordening.

Wetten die door de aanvullingswetten worden ingetrokken zijn:

- de Wet agrarisch grondverkeer;

- de Wet bodembescherming;

- de Wet geluidhinder;

- de Wet inrichting landelijk gebied;

- de Wet natuurbescherming;

- de Wet voorkeursrecht gemeenten. 
daarbij om:

- de Mijnbouwwet: milieuregelgeving voor de exclusieve economische zone en de veiligheidszone;

- de Monumentenwet 1988/Erfgoedwet: de vergunning voor archeologische rijksmonumenten, beschermde stads- en dorpsgezichten en archeologische monumentenzorg in bestemmingsplannen;

- de onteigeningswet;

- de Spoorwegwet en de Wet lokaal spoor: het omgevingsregime;

- de Waterwet, behalve de regelingen voor het deltaprogramma en het financiële hoofdstuk;

- de Wet beheer rijkswaterstaatswerken: het vergunningstelsel;

- de Wet bereikbaarheid en mobiliteit: ruimtelijke doorwerking;

- de Wet luchtvaart: ruimtelijke beperkingen;

- de Wet milieubeheer: de regelgeving over plaatsgebonden activiteiten;

- de Woningwet: de bouwregelgeving;

- gedoogplichten uit diverse wetten.

Deze laatste categorie betreft deels wetten die ook andere regels bevatten dan regels over de fysieke leefomgeving of regels met een overwegend ander motief. Zo bevat de Woningwet regels over woningbouwcorporaties. Die vallen buiten het kader van de Omgevingswet. Deels gaat het om wetten, zoals de Waterwet en de Wet milieubeheer, die ook onderwerpen bevatten die in de toekomst in de Omgevingswet opgenomen zouden kunnen worden. In de memorie van toelichting worden in dat verband regels genoemd over niet-plaatsgebonden activiteiten, zoals regels over (afval)stoffen of producten, en regels over financiële instrumenten. ${ }^{\mathbf{2 0}}$ Daarbij wordt ook een doorkijkje gegeven naar de mogelijke integratie van andere wetten op het gebied van waterwetgeving en wegbeheer, in volgende modules. ${ }^{\mathbf{2 1}}$

\subsubsection{Algemene maatregelen van bestuur en Omgevingsregeling}

De Omgevingswet vormt de basis voor AMvB's. Die geven nadere uitwerking aan de Omgevingswet en bevatten een belangrijk deel van de inhoudelijke regels over de fysieke leefomgeving en over activiteiten met gevolgen voor de fysieke leefomgeving. Ze vormen het hart van het nieuwe stelsel. De AMvB's vervangen regels in zo'n zestig bestaande besluiten, waaronder het Besluit algemene regels ruimtelijke ordening, het Besluit omgevingsrecht, het Besluit milieueffectrapportage, het Waterbesluit, het Activiteitenbesluit milieubeheer en het Bouwbesluit 2012. 
De AMvB's bevatten regels over belangrijke onderwerpen, zoals omgevingswaarden (doelstellingen voor de gewenste staat of kwaliteit van de fysieke leefomgeving met bepaalde, in de wet aangegeven rechtsgevolgen), instructieregels (regels over de uitoefening van taken en bevoegdheden door bestuursorganen), de aanwijzing van vergunningplichtige activiteiten en algemene rijksregels over activiteiten in de fysieke leefomgeving op het gebied van onder meer milieu, water en bouwen. Deze regels zijn in vier AMvB's opgenomen. Deze zijn, zoals de volgende figuur ${ }^{\mathbf{2 2}}$ weergeeft, geordend naar soort regels en doelgroep.

Figuur 1.1 - de indeling van de AMvB's

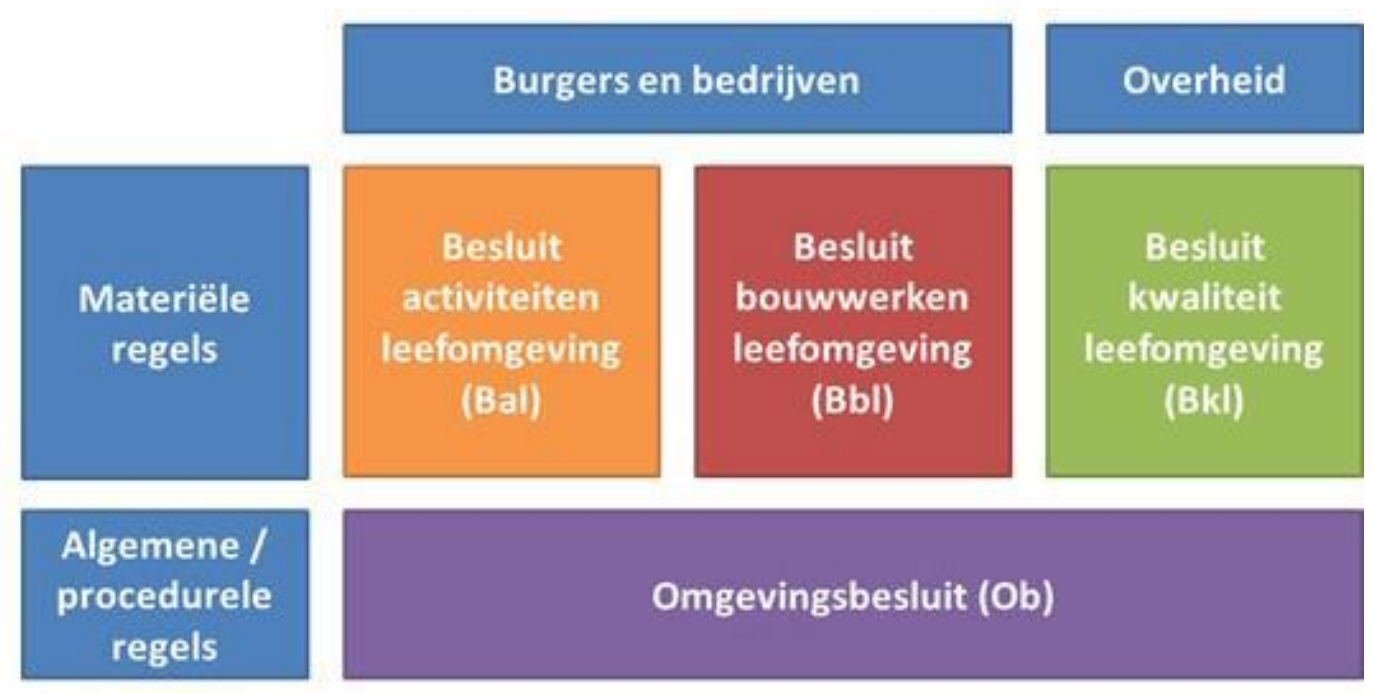

De AMvB's kunnen als volgt worden gekenschetst:

- Het Besluit activiteiten leefomgeving (Bal) bevat inhoudelijke regels die het Rijk stelt over een breed scala aan activiteiten in de fysieke leefomgeving. Het gaat daarbij vooral om milieubelastende activiteiten en wateractiviteiten. Daarnaast bevat het besluit regels over onder meer activiteiten rondom wegen en waterstaatwerken en activiteiten die betrekking hebben op cultureel erfgoed. Regels over activiteiten met betrekking tot bouwwerken zijn opgenomen in het Besluit bouwwerken leefomgeving. Het Besluit activiteiten leefomgeving beschrijft welke inhoudelijke regels gelden en welke ruimte er is voor maatwerk ${ }^{\mathbf{2 3}}$ of gelijkwaardige maatregelen ${ }^{\mathbf{2 4}}$. Ook bepaalt het wanneer voor de activiteit een omgevingsvergunning nodig is. De regels richten zich tot eenieder die die activiteiten verricht. Dit kan een burger zijn of een bedrijf, maar ook de overheid in de rol van initiatiefnemer.

- Het Besluit bouwwerken leefomgeving (Bbl) bevat inhoudelijke regels over activiteiten met betrekking tot het bouwen, in stand houden, gebruik en slopen van bouwwerken. Het beschrijft welke inhoudelijke regels gelden en welke ruimte er is voor maatwerk of gelijkwaardige maatregelen. Ook bepaalt het wanneer voor de activiteit een omgevingsvergunning nodig is. De regels richten zich tot eenieder die die activiteiten verricht. Dit kan een burger zijn of een bedrijf, maar ook de overheid in de rol van initiatiefnemer.

- Het Omgevingsbesluit (Ob) bevat regels over procedurele en 
algemene onderwerpen. Het geeft, in aanvulling op hoofdstuk 16 van de Omgevingswet, onder meer aan welke procedures moeten worden doorlopen, bijvoorbeeld bij de aanvraag om een omgevingsvergunning, en wie het bevoegd gezag is. Ook regels over algemene onderwerpen zoals milieueffectrapportage, kostenverhaal en financiële zekerheidsstelling zijn in dit besluit opgenomen.

- Het Besluit kwaliteit leefomgeving (Bkl) bevat inhoudelijke regels voor bestuursorganen van gemeenten, waterschappen, provincies en het Rijk. Het besluit is ingedeeld naar de instrumenten van de Omgevingswet, zoals omgevingswaarden, omgevingsplannen, omgevingsverordeningen, projectbesluiten en monitoring. De regels van het besluit gaan over de uitoefening van taken en bevoegdheden voor de fysieke leefomgeving, zoals het vaststellen van een omgevingsplan en het verlenen van omgevingsvergunningen. De regels werken niet rechtstreeks naar burgers en bedrijven.

Tot slot wordt een deel van de regels van de Omgevingswet uitgewerkt op het niveau van een ministeriële regeling, in de voorgenomen Omgevingsregeling. Het betreft voornamelijk regels van uitvoeringstechnische of administratieve aard en meet- en rekenvoorschriften. Deze regels zijn van belang voor de concrete uitvoering van het nieuwe stelsel. Ze gaan onder meer over de aanwijzing en begrenzing van locaties, bijvoorbeeld van wateren en gebieden, gegevens en bescheiden die bij aanvragen moeten worden verstrekt en regels over het digitale stelsel.

Gedurende het totstandkomingsproces van het nieuwe stelsel is de verdeling van regels over de drie niveaus (wet, $\mathrm{AMvB}$ of ministeriële regeling) een onderwerp van discussie geweest. Belangrijke elementen in de discussie waren de mate van inhoudelijke sturing vanuit de wet en de betrokkenheid van het parlement. Dit heeft er onder meer toe geleid dat in de wet enkele waarborgen zijn opgenomen. Zo wordt bij de totstandkoming en wijzigingen van de AMvB's een voorhangprocedure bij het parlement gevolgd. Dat betekent dat het ontwerp van de AMvB's aan beide Kamers wordt voorgelegd, zodat er een brede politiek-maatschappelijke discussie over plaats kan vinden.

Voor de toepassing van de regels is het van belang op te merken dat de onderverdeling van de regels in wet, $\mathrm{AMvB}$ of ministeriële regeling geen gevolgen heeft voor hun juridische geldingskracht. Het gaat in al die gevallen om algemeen verbindende voorschriften die, zoals de term al zegt, bindend zijn voor iedereen tot wie de regels zijn gericht.

\subsubsection{Invoeringsregelgeving}

De invoeringsregelgeving zorgt ervoor dat het nieuwe stelsel op een goede wijze ingevoerd kan worden. Ten eerste zorgt de invoeringsregelgeving voor de aanpassing van andere regelgeving aan het nieuwe stelsel van het omgevingsrecht. Die aanpassing kan bestaan uit het wijzigen of het geheel of gedeeltelijk intrekken van bestaande regelgeving. Dat geldt bijvoorbeeld voor de in paragraaf 1.5.2 genoemde wetten. Een ander belangrijk onderdeel van de invoeringsregelgeving is het overgangsrecht. Dit zorgt voor continuiteit en rechtszekerheid voor bestaande rechten en plichten, zoals vergunningen of gedoogplichten. Met het overgangsrecht wordt een rechtsvacuüm voorkomen. 
Ook bevat het overgangsrecht regels voor lopende procedures en termijnen waarbinnen bijvoorbeeld bepaalde visies, plannen of programma's vastgesteld moeten zijn. Op elk regelgevingsniveau is overgangsrecht nodig. De invoeringsregelgeving zal daarom bestaan uit de Invoeringswet Omgevingswet, het Invoeringsbesluit Omgevingswet en de Invoeringsregeling Omgevingswet (hierna: Invoeringswet, Invoeringsbesluit en Invoeringsregeling).

Daarnaast zal de Invoeringswet de Omgevingswet met enkele onderwerpen uitbreiden. Het gaat onder meer om regels op het gebied van schade, punitieve handhaving en het Digitaal Stelsel Omgevingswet (DSO). Hiervoor zijn in de Omgevingswet al onderdelen gereserveerd. Ook zullen nog enkele aanvullende wijzigingen worden aangebracht in verband met inmiddels in werking getreden nieuwe wetgeving op het gebied van waterveiligheid, milieu-effectrapportage en vergunningverlening, toezicht en handhaving. ${ }^{\mathbf{2 5 2 6}}$ Op die manier zorgt de Invoeringswet ervoor dat het stelsel bij inwerkingtreding actueel is. Verder wordt nog een aantal andere wijzigingen aangebracht. Deze wijzigen het systeem van de Omgevingswet niet. Wel worden de regels over de kerninstrumenten via de Invoeringswet op onderdelen verduidelijkt of anderszins in beperkte mate aangepast. Zo wordt het onder meer mogelijk om in het omgevingsplan zogenoemde voorbeschermingsregels ${ }^{\mathbf{2 7}}$ op te nemen.

De wijzigingen die in de invoeringsregelgeving zijn opgenomen treden tegelijk met de Omgevingswet in werking. Op dat moment gaan de wijzigingen van de Omgevingswet die in de Invoeringswet zijn opgenomen op in de Omgevingswet. De Invoeringswet houdt daarvoor geen zelfstandige betekenis. De Invoeringswet blijft nog wel van betekenis gedurende de looptijd van het daarin opgenomen overgangsrecht. Hetzelfde geldt voor de regels in het Invoeringsbesluit en de Invoeringsregeling. Als er geen overgangsrecht is opgenomen, gelden vanaf de datum van inwerkingtreding de regels van het nieuwe stelsel.

\subsubsection{Aanvullingsregelgeving}

De aanvullingsregelgeving, de naam zegt het al, vult het stelsel van de Omgevingswet aan. De aanvullingsregelgeving heeft betrekking op de onderwerpen bodem, geluid, natuur en grondeigendom. Dit gaat vaak gepaard met beleidsinhoudelijke wijzigingen die niet direct voortvloeien uit de stelselherziening. Vandaar dat die in afzonderlijke aanvullingssporen zijn ondergebracht. Dat maakt het mogelijk om de voorbereiding en besluitvorming over deze regelgeving separaat te laten plaatsvinden. Het is de bedoeling dat de aanvullingsregelgeving tegelijk met het hoofd- en invoeringsspoor in werking treedt. Hieronder worden de verschillende aanvullingssporen alleen kort geduid.

\section{Bodem}

Via dit aanvullingsspoor zullen de regels over bodem een plaats krijgen in het stelsel van de Omgevingswet. De nieuwe regels maken zoveel mogelijk gebruik van de instrumenten van de Omgevingswet, zoals het omgevingsplan en de algemene rijksregels over activiteiten in de fysieke leefomgeving. De aanvullingen zijn op wetsniveau dan ook beperkt van omvang. ${ }^{\mathbf{2 8}}$ In de memorie van toelichting bij het wetsvoorstel voor de Aanvullingsbodem Omgevingswet is al wel een beschrijving opgenomen van het voorgenomen nieuwe beleid en de 
werking van de toekomstige bodemregels. Preventie staat daarbij voorop. Met behulp van zorgplichten en algemene regels wordt beoogd om nieuwe verontreinigingen en aantasting te voorkomen. Daarnaast beoogt het voorstel het belang van de bodemkwaliteit al vroegtijdig te betrekken bij het integrale beleid en de regelgeving over de ontwikkeling en het beheer van de fysieke leefomgeving. De omgevingsvisie en het omgevingsplan zijn daarvoor belangrijke instrumenten. Ook bevat het voorstel regels over het beheer van historische verontreinigingen. Met behulp van locatiespecifieke regels kan de voorgeschreven kwaliteit worden toegesneden op de locatie en de daar voorkomende activiteiten. Daarbij blijft het oogmerk van de regels de bescherming van de gezondheid en het milieu. In dit aanvullingsspoor wordt uitgegaan van de benodigde bodemkwaliteit op een locatie in relatie tot het (gewenste) gebruik, en niet langer van 'een geval van verontreiniging' met de daarbij behorende verplichtingen als bedoeld in de huidige Wet bodembescherming. Deze beleidswijziging houdt verband met de afronding van de aanpak van spoedlocaties. ${ }^{\mathbf{2 9}}$ De materiële regels over bodem zullen in belangrijke mate worden uitgewerkt in de uitvoeringsregelgeving. Dit gebeurt hoofdzakelijk door middel van het Aanvullingsbesluit bodem Omgevingswet, dat aanvullingen bevat van de AMvB's op grond van de Omgevingswet. Zo worden er specifieke regels over milieubelastende activiteiten, zoals het graven in de bodem en het gebruik van meststoffen, aan het Besluit activiteiten leefomgeving toegevoegd. Ook worden er aan het Besluit kwaliteit leefomgeving instructieregels toegevoegd over het bouwen op verontreinigde grond en over het toepassen van grond en baggerspecie. Het ontwerpbesluit is voor openbare consultatie op internet gepubliceerd. ${ }^{30}$

\section{Natuur}

Via het aanvullingsspoor natuur wordt de inhoud van de regels op grond van de Wet natuurbescherming in het stelsel van de Omgevingswet opgenomen. ${ }^{\mathbf{1 1}}$ Die regels worden zoveel mogelijk beleidsneutraal, dat wil zeggen met een gelijkwaardig beschermingsniveau, ingepast. Het gaat daarbij om alle regels uit de Wet natuurbescherming. Dus naast de regels over de bescherming van soorten en gebieden, zoals het Natuurnetwerk Nederland, ook de regels over faunabeheer, bestrijding van schadeveroorzakende dieren en de jacht, en de regels over de handel in dieren en planten van bedreigde soorten (Citesverdrag). Hiervoor zullen in de Omgevingswet enkele specifieke grondslagen worden opgenomen. Dat geldt ook voor de regels over de passende beoordeling van plannen en projecten en de aanwijzing van Natura 200o-gebieden. Verder wordt zoveel mogelijk aangesloten bij instrumenten van de Omgevingswet, zoals instructieregels, de omgevingsverordening, het omgevingsplan, algemene rijksregels en de omgevingsvergunning. Voor enkele instrumenten, zoals de omgevingsvisie en beheerplannen, zijn de regels over natuur al in de Omgevingswet opgenomen. De uitwerking van de regels vindt via het Aanvullingsbesluit natuur Omgevingswet plaats in de AMvB's op grond van de Omgevingswet. Zo zullen in het Besluit activiteiten leefomgeving vergunningplichtige activiteiten worden aangewezen ter bescherming van Natura 2000-gebieden en van bepaalde dier- en plantensoorten. In het Besluit kwaliteit leefomgeving zullen met het oog op de bescherming van de natuur onder meer instructieregels worden opgenomen voor omgevingsverordeningen en omgevingsplannen en zullen de beoordelingsregels voor omgevingsvergunningen worden aangevuld. Het ontwerp van het aanvullingsbesluit zal naar verwachting eind 2018 gereed zijn voor 
internetconsultatie.

\section{Geluid}

De Omgevingswet en de daarop gebaseerde AMvB's bevatten al regels over geluid, onder meer over actieplannen en geluidbelastingkaarten ter implementatie van de richtlijn omgevingslawaai en over geluidbelasting door activiteiten in de fysieke leefomgeving. Via het aanvullingsspoor zullen de regels over geluid afkomstig van infrastructuur en industrieterreinen een plaats krijgen in het stelsel van de Omgevingswet. Deze regels zullen met name betrekking hebben op de beheersing van geluid afkomstig van wegen (in beheer bij Rijk, provincie, gemeente en waterschap), spoorwegen en bepaalde industrieterreinen. Zij strekken ter vervanging van de regels over geluidproductieplafonds die nu in de Wet geluidhinder en hoofdstuk 11 van de Wet milieubeheer zijn opgenomen. De toepassing van die regels zal worden verbreed van rijkswegen naar decentrale infrastructuur en bepaalde industrieterreinen. Bij de omzetting wordt zo veel mogelijk aangesloten bij de (kern)instrumenten van de Omgevingswet. De aanvullingen zijn op wetsniveau dan ook beperkt van omvang. ${ }^{\mathbf{2}}$ Daarbij wordt het instrument van de omgevingswaarde zo aangepast dat bij besluit geluidproductieplafonds als omgevingswaarde kunnen worden vastgesteld. Op gemeentelijk niveau komen de geluidproductieplafonds samen met andere omgevingswaarden in het omgevingsplan terecht. Verder wordt geregeld dat bij een dreigende overschrijding van een omgevingswaarde een maatregelplicht in plaats van een programmaplicht kan worden opgelegd. Op die manier kan in bepaalde gevallen efficiënter aan de omgevingswaarde worden voldaan. De uitwerking zal voornamelijk een plaats krijgen in de uitvoeringsregelgeving (in het bijzonder het Besluit kwaliteit leefomgeving). In de memorie van toelichting bij het wetsvoorstel is al wel een beschrijving opgenomen van het voorgenomen nieuwe beleid en de werking van de toekomstige geluidregels.

\section{Grondeigendom}

Via de aanvullingsregelgeving over grondeigendom worden regels over onteigening, landinrichting, stedelijke kavelruil en het voorkeursrecht toegevoegd aan het stelsel van de Omgevingswet. Daarnaast worden wijzigingen aangebracht in de regeling over grondexploitatie (kostenverhaal). Het stelsel krijgt daarmee diverse instrumenten voor actief en faciliterend grondbeleid. Deze instrumenten zijn van belang voor het beheren, gebruiken en ontwikkelen van de fysieke leefomgeving - en daarmee voor het bereiken van de maatschappelijke doelen van de Omgevingswet. Deze wettelijke instrumenten maken het voor de overheid mogelijk om in meer of mindere mate inbreuk te maken op de rechtspositie van eigenaren van onroerende zaken en in samenhang daarmee ook op de rechtspositie van zakelijk of persoonlijk gerechtigden. Deze regels zijn dan ook niet alleen bestuursrechtelijk maar ook privaatrechtelijk relevant.

Met de inbouw van deze regels in het stelsel van de Omgevingswet zullen bestaande instrumenten worden afgestemd op de begrippen en instrumenten van de Omgevingswet. Zo wordt een landinrichtingsplan, vanwege de scheiding tussen beleid en normstelling in de instrumenten van de Omgevingswet, gesplitst in een inrichtingsprogramma en -besluit. Bij de instrumenten kavelruil en het voorkeursrecht blijven bestaande functionaliteiten en 
toepassingsmogelijkheden van deze instrumenten behouden. Wel zal de toepassing worden toegesneden op de nieuwe instrumenten van de Omgevingswet, zoals het omgevingsplan en de omgevingsverordening. De belangrijkste inhoudelijke vernieuwingen betreffen de regels over kostenverhaal, onteigening en vrijwillige stedelijke kavelruil.

\section{Zwemmen of baden in waterbassins}

De Omgevingswet bevat al een grondslag voor het stellen van algemene regels over het gelegenheid bieden tot zwemmen of baden. ${ }^{33}$ Een

aanvullingswetsvoorstel is daarom niet nodig. De inhoudelijke regels zullen in het Besluit activiteiten leefomgeving worden opgenomen en vervangen de regels over badinrichtingen die zijn opgenomen in het Besluit hygiëne en veiligheid badinrichtingen en zwemgelegenheden (Bhvbz). In het Besluit activiteiten leefomgeving was daarvoor al een hoofdstuk gereserveerd. Aangezien de regels niet alleen in het stelsel worden ingebouwd maar ook inhoudelijk worden gewijzigd, gebeurt dat via het Aanvullingsbesluit zwemmen of baden in waterbassins Omgevingswet. Met dit aanvullingsbesluit worden alleen de regels over de voormalige badinrichtingen opgenomen in het Besluit activiteiten leefomgeving. De regels over zwemlocaties (bijvoorbeeld oppervlaktewateren) zijn al in het Besluit kwaliteit leefomgeving opgenomen. Doel van de regels is om de gezondheid en veiligheid van de gebruikers van waterbassins op een adequate manier te beschermen. Tegelijkertijd krijgt degene die hiertoe de gelegenheid biedt meer mogelijkheden om zelf te bepalen met welke maatregelen hij de gezondheid en veiligheid van de gebruikers beschermt. Daarvoor is wel vereist dat de exploitant een risicoanalyse uitvoert en beheersmaatregelen neemt. In de nieuwe regels wordt zoveel mogelijk aangesloten bij de instrumenten van de Omgevingswet en het Besluit activiteiten leefomgeving, zoals de specifieke zorgplicht, maatwerk en de melding. Verder wordt meer uitgegaan van doelvoorschriften dan van gedetailleerde middelvoorschriften.

\subsubsection{Digitaal Stelsel Omgevingswet (DSO)}

Digitalisering is een belangrijk hulpmiddel bij de uitvoering van de Omgevingswet en draagt bij aan het vergroten van de toegankelijkheid van het omgevingsrecht voor gebruikers. De uitvoering van de omgevingsrechtelijke regels zal daarom worden ondersteund via het Digitaal Stelsel Omgevingswet. ${ }^{\mathbf{3 4}}$ Centraal onderdeel hiervan is de landelijke voorziening. 35 Die vervult een loketfunctie voor het aanvragen van vergunningen (zoals het huidige Omgevingsloket-online), het doen van meldingen (zoals de huidige Activiteitenbesluit Internet Module (AIM)) en het voldoen aan informatieverplichtingen. Via dit digitale loket kan een belanghebbende ook aanvragen doen voor maatwerkvoorschriften of toestemmingen om een gelijkwaardige maatregel te treffen. Deze aanvraag, melding of informatie wordt vervolgens via de landelijke voorziening doorgeleid naar het bevoegd gezag. Het gebruik van dit loket is verplicht als een initiatiefnemer de elektronische weg benut. Het blijft onder de Omgevingswet mogelijk om, in de gevallen waarin niet exclusief de elektronische weg is voorgeschreven, op papier een vergunning aan te vragen, een melding te doen of gegevens en bescheiden aan het bevoegd gezag te verstrekken. ${ }^{\mathbf{3 6}}$

Een tweede functie betreft het digitaal ontsluiten van informatie over geldende regels en besluiten (zoals het huidige ruimtelijkeplannen.nl). Via deze 
landelijke voorziening zullen in ieder geval de relevante onderdelen van de AMvB's en de Omgevingsregeling en de nationale omgevingsvisie worden ontsloten. Deze informatie kan vervolgens worden aangevuld met informatie over regels uit het omgevingsplan, de waterschapsverordening en de omgevingsverordening. In de toekomst kan de informatie worden uitgebreid met informatie over andere besluiten of rechtsfiguren op grond van de Omgevingswet, zoals omgevingsvergunningen.

Het streefbeeld is om de informatievoorziening zo in te richten dat de informatie zoveel mogelijk objectgericht, met een "klik op de kaart", kan worden opgeroepen. Verder zullen er hulpmiddelen, in de vorm van vragenbomen, beschikbaar zijn die gebruikers helpen bij de vraag of er voor hun voorgenomen activiteit een verbod geldt om de activiteit te verrichten zonder omgevingsvergunning of een voorafgaande melding aan het bevoegd gezag.

Een derde functie betreft het ontsluiten van informatie en gegevens over (de staat van) de fysieke leefomgeving. Er is al veel informatie beschikbaar over verschillende onderdelen van de fysieke leefomgeving, bijvoorbeeld informatie over luchtkwaliteit, waterkwaliteit en verwachtingen over archeologische of natuurwaarden. Via het DSO kan informatie over de fysieke leefomgeving die elders al in bruikbare vorm digitaal beschikbaar is, worden ontsloten door een technische koppeling (link) met de vindplaats.

Voor een goede uitvoering van de functies van het DSO zijn regels nodig over gemeenschappelijke definities en standaarden, de kwaliteit van de beschikbare informatie en de verstrekking van informatie. Ook zullen regels worden gesteld over taken en verantwoordelijkheden van de diverse organisaties en beheerders. Zo is de Minister van Binnenlandse Zaken en Koninkrijksrelaties als beheerder operationeel verantwoordelijk voor de landelijke voorziening. Daarnaast berust bij de Minister het interbestuurlijk toezicht op de taakuitoefening in het kader van het DSO. De basis voor die regels zal via de Invoeringswet in de Omgevingswet worden opgenomen. De uitwerking daarvan, onder meer van de digitale standaarden waaraan de informatie moet voldoen, zal (via het Invoeringsbesluit en de Invoeringsregeling) een plek krijgen in het Omgevingsbesluit en de Omgevingsregeling. Daarnaast zullen interbestuurlijke afspraken worden gemaakt over de samenwerking bij en financiering van de ontwikkeling en het beheer van het DSO.

\section{Systeem, toepassingsgebied en doelen van de Omgevingswet}

\subsection{Systematiek}

\subsubsection{Architectuur van de wetgeving}

Zoals in paragraaf 1.3 is beschreven, is de stelselherziening onder meer gericht op het vergroten van de inzichtelijkheid, de voorspelbaarheid en het gebruiksgemak van het omgevingsrecht. Toegankelijkheid begint met een heldere structuur. De huidige regelgeving op het gebied van het omgevingsrecht is complex en versnipperd. Dat maakt dit rechtsgebied voor de gebruiker lastig te doorgronden. De stelselherziening beoogt het omgevingsrecht op te bouwen volgens een eenduidige systematiek. Dit komt onder meer tot uiting bij de opbouw van het totale stelsel, de keuze voor een gereedschapskist met een beperkt aantal kerninstrumenten en de gehanteerde terminologie. De laatste twee onderwerpen worden in de paragrafen 2.1.2 en 


\subsection{3 nader uitgewerkt.}

Bij de opbouw en indeling van het nieuwe wettelijke stelsel van het omgevingsrecht is een aantal indelingsprincipes gehanteerd. Deze zijn gericht op een heldere ordening van de regels. Het eerste indelingsprincipe is een zogenoemde doelgroepenbenadering bij het rangschikken van de regels en het maken van onderscheid tussen inhoudelijke en procedurele regels. De doelgroepenbenadering houdt in dat is bekeken tot wie de regels zich richten: tot bestuursorganen of tot burgers en bedrijven? De hoofdstukindeling van de Omgevingswet is mede gebaseerd op deze doelgroepenbenadering.
Zo zijn de hoofdstukken 2 (Taken en bevoegdheden van bestuursorganen) en 3 (Omgevingsvisies en programma's) primair gericht tot bestuursorganen. Hoofdstuk 4 (Algemene regels over activiteiten in de fysieke leefomgeving) en hoofdstuk 5 (De omgevingsvergunning en het projectbesluit) richten zich tot een ieder die activiteiten verricht of wil gaan verrichten in de fysieke leefomgeving.

Zoals in paragraaf 1.5.3 is beschreven, zijn ook de vier AMvB's naar doelgroep geordend. Daarbij geldt dat het Besluit kwaliteit leefomgeving zich uitsluitend tot bestuursorganen richt. De drie andere AMvB's richten zich tot eenieder die activiteiten verricht of wil gaan verrichten in de fysieke leefomgeving. Het Besluit bouwwerken leefomgeving en het Besluit activiteiten leefomgeving richten zich vervolgens naar doelgroepen voor activiteiten: activiteiten met betrekking tot bouwwerken respectievelijk andere activiteiten. Ook is onderscheid gemaakt tussen inhoudelijke regels en procedurele regels. Die lopen in de huidige regelgeving nogal eens door elkaar. In het stelsel van de Omgevingswet worden inhoudelijke en procedurele regels van elkaar gescheiden en op herkenbare plaatsen in het wettelijke stelsel opgenomen. Op AMvB-niveau zijn de procedurele en algemene regels in het Omgevingsbesluit gebundeld.

Het tweede belangrijke indelingsprincipe is dat inhoudelijke regels op $A M v B$ niveau worden gesteld. Dit houdt verband met principiële keuzes die de wetgever heeft gemaakt bij de verdeling van onderwerpen over de verschillende niveaus van regelgeving (delegatiebeleid). Dit onderwerp heeft veel aandacht gekregen in het advies van de Afdeling advisering van de Raad van State ${ }^{37}$ en bij de behandeling van het wetsvoorstel Omgevingswet in de Tweede en Eerste Kamer. ${ }^{38}$
Naar aanleiding van het advies van de Afdeling advisering van de Raad van State is het wetsvoorstel Omgevingswet voorafgaand aan indiening bij de Tweede Kamer op diverse punten aangepast. De sturing door de formele wetgever is versterkt door regelgevende bevoegdheden te begrenzen en door op wetsniveau meer inzicht te geven in de bevoegdheidsverdeling. Andere wijzigingen zijn het nader inkaderen van flexibiliteitsinstrumenten zoals maatwerkregels en -voorschriften. Bij de Tweede Kamerbehandeling zijn bij amendement extra waarborgen opgenomen voor de betrokkenheid van het parlement bij de totstandkoming van AMvB's die op grond van de Omgevingswet worden vastgesteld.

Inhoudelijke regels zijn regels die inhoudelijke sturing geven aan de uitoefening van bevoegdheden of taken door bestuursorganen (zogenoemde 
instructieregels, opgenomen in het Besluit kwaliteit leefomgeving) en direct werkende regels voor burgers en bedrijven (opgenomen in het Besluit activiteiten leefomgeving en het Besluit bouwwerken leefomgeving). Instructieregels zijn bijvoorbeeld regels die door het Rijk worden gesteld over de inhoud van een omgevingsplan, zoals regels over externe veiligheid of over ruimtelijke reserveringen voor energie-infrastructuur. Voorbeelden van algemene regels zijn regels over het opslaan van gevaarlijke stoffen of over het bouwen van woningen.

Bij de advisering over het wetsvoorstel Aanvullingswet bodem Omgevingswet in 2017 gaat de Afdeling advisering van de Raad van State specifiek in op de systeemkeuze in de Omgevingswet om de materiële normstelling grotendeels te bundelen in een beperkt aantal AMvB's. De Afdeling wijst op enkele wijzigingen, die mede naar aanleiding van het eerdere advies van de Afdeling in de Omgevingswet zijn aangebracht, waarmee de delegatiegrondslagen in de Omgevingswet nader met waarborgen zijn omkleed. De Afdeling geeft vervolgens expliciet aan dat zij de door de wetgever bij de Omgevingswet gemaakte keuzes voor het nieuwe stelsel, waaronder de keuze van de AMvB als basisniveau voor inhoudelijke normstelling, als uitgangspunt neemt voor de verdere advisering. ${ }^{39}$ In het advies over de AMvB's en het voorstel voor de Invoeringswet is dat uitgangspunt bevestigd en gecontinueerd.

Vanwege het primaat van de wetgever zijn sommige fundamentele onderwerpen overigens wel in de Omgevingswet zelf verankerd. Voorbeelden hiervan zijn grondslagen voor vergunningstelsels, de hoofdlijnen van de regeling van het bevoegd gezag bij de omgevingsvergunning, bevoegdheden die kunnen ingrijpen in het eigendomsrecht (bijvoorbeeld regels over gedoogplichten of onteigening) en rechtsbescherming bij de bestuursrechter.

Het derde indelingsprincipe is het hanteren van een vaste volgorde van bestuurslagen. In de Omgevingswet en de daarop gebaseerde uitvoeringsregelgeving wordt consequent, en in lijn met het uitgangspunt 'decentraal, tenzij', als volgorde van bestuurslagen gehanteerd: gemeente, waterschap, provincie, Rijk. Dit gebeurt op hoofdstukniveau, maar daarbinnen ook in paragrafen, artikelen en opsommingen binnen een artikel. Dit vergroot de toegankelijkheid van de regelgeving voor de gebruiker.

\subsubsection{Kerninstrumenten}

In de Omgevingswet staat een zestal kerninstrumenten centraal. Deze instrumenten vormen de ruggengraat van de wet. Hieronder worden ze kort geduid.

\section{Omgevingsvisie}

De omgevingsvisie bevat een integrale langetermijnvisie op de noodzakelijke en de gewenste ontwikkelingen van de fysieke leefomgeving in een gemeente of een provincie of voor Nederland als geheel. Het is een politiek-bestuurlijk document dat in beginsel alleen het vaststellende bestuursorgaan zelf bindt. De Omgevingswet voorziet niet in een omgevingsvisie voor waterschappen. Dit komt omdat het hier om functioneel bestuur gaat. De omgevingsvisie is geregeld in hoofdstuk 3 van de Omgevingswet. 
Een programma bevat een pakket van beleidsvoornemens en maatregelen om omgevingswaarden of andere doelstellingen voor de fysieke leefomgeving te bereiken. Een programma kan een sectoraal of gebiedsgericht karakter hebben. Een bijzondere variant is een programma met een programmatische aanpak. ${ }^{40}$ Programma's zijn geregeld in hoofdstuk 3 van de Omgevingswet.

\section{Decentrale algemene regels}

Wanneer op decentraal niveau bindende regels over de fysieke leefomgeving worden gesteld, gebeurt dit in het omgevingsplan van de gemeente, de waterschapsverordening en de omgevingsverordening van de provincie. Het bijeenbrengen van regels over de fysieke leefomgeving in één gebiedsdekkende regeling per bestuurslaag bevordert de inzichtelijkheid en de samenhang van de regelgeving. De grondslagen voor deze decentrale algemene regels zijn opgenomen in afdeling 2.2 en hoofdstuk 4 van de Omgevingswet.

\section{Algemene rijksregels over activiteiten in de fysieke leefomgeving}

Wanneer het gewenst is om op nationaal niveau regels te stellen over activiteiten in de fysieke leefomgeving, wordt waar mogelijk het instrument algemene regels (voor eenieder geldende regels) ingezet. Deze regels worden in beginsel gesteld bij AMvB. ${ }^{\mathbf{4 1}}$ De basis voor deze regels ligt in hoofdstuk 4 van de Omgevingswet.

\section{Omgevingsvergunning}

De Omgevingswet bevat één vergunning voor activiteiten met (mogelijke) gevolgen voor de fysieke leefomgeving: de omgevingsvergunning. Het kan daarbij gaan om toestemmingen van zowel gemeenten, waterschappen en provincies als het Rijk. Het is een instrument waarbij de overheid vooraf toetst of bepaalde activiteiten kunnen worden verricht en, zo ja, onder welke voorwaarden. De omgevingsvergunning is geregeld in afdeling 5.1 van de Omgevingswet.

\section{Projectbesluit}

Afdeling 5.2 (Projectprocedure) van de Omgevingswet biedt een generieke regeling voor besluitvorming over projecten met een publiek belang van het Rijk, een provincie of een waterschap. Het gaat om projecten die bestaan uit het bouwen van bouwwerken of het totstandbrengen van werken of installaties of andere activiteiten die onderdelen van de fysieke leefomgeving wijzigen.

Vaststelling van een projectbesluit maakt het uitvoeren en in werking hebben of in stand houden van een project mogelijk. Toestemmingen, zoals omgevingsvergunningen, kunnen deel uitmaken van een projectbesluit.

De Omgevingswet kent geen projectbesluit op gemeentelijk niveau. Gemeenten kunnen projecten die niet passen binnen het geldende omgevingsplan mogelijk maken door het wijzigen van het omgevingsplan..$^{\mathbf{2}}$ Voor gemeentelijke projecten van publiek belang bevat de Omgevingswet een procedure voor de voorbereiding van wijzigingen van het omgevingsplan met toepassing van de 'sneller en beter'-aanpak (artikel 5.55 Omgevingswet). De procedure van het projectbesluit is dan grotendeels van overeenkomstige toepassing. 
De belangrijkste instrumenten van de Omgevingswet zijn in onderstaande tabel schematisch weergegeven. ${ }^{43}$ De tabel bevat per instrument een inhoudelijke duiding, de vindplaats van de regels in de wet en een korte typering.

\begin{tabular}{|c|c|c|c|}
\hline Instrument & Inhoud & Omgevingswet & Typering \\
\hline Omgevingsvisie & $\begin{array}{l}\text { Integrale } \\
\text { langetermijnvisie op } \\
\text { voorgenomen } \\
\text { ontwikkelingen van de } \\
\text { fysieke leefomgeving }\end{array}$ & Afdeling 3.1 & Beleidsontwikkeling \\
\hline Programma & $\begin{array}{l}\text { Pakket van } \\
\text { beleidsvoornemens en } \\
\text { maatregelen om } \\
\text { doelstellingen voor de } \\
\text { fysieke leefomgeving te } \\
\text { bereiken }\end{array}$ & Afdeling 3.2 & Beleidsontwikkeling \\
\hline Instructieregel & $\begin{array}{l}\text { Regel over de } \\
\text { uitoefening van een taak } \\
\text { of bevoegdheid door een } \\
\text { bestuursorgaan }\end{array}$ & Paragraaf 2.5.1 & Beleidsdoorwerking \\
\hline Beoordelingsregel & $\begin{array}{l}\text { Regel over het verlenen } \\
\text { of weigeren van een } \\
\text { omgevingsvergunning }\end{array}$ & Paragraaf 5.1.3 & Beleidsdoorwerking \\
\hline $\begin{array}{l}\text { Decentrale algemene } \\
\text { regels }\end{array}$ & $\begin{array}{l}\text { Voor een ieder geldende } \\
\text { regels in een } \\
\text { omgevingsplan, } \\
\text { waterschapsverordening } \\
\text { of } \\
\text { omgevingsverordening }\end{array}$ & $\begin{array}{l}\text { Afdelingen } 2.2 \\
\text { en } 4.1\end{array}$ & Algemene regels \\
\hline Algemene rijksregels & $\begin{array}{l}\text { Voor eenieder geldende } \\
\text { regels in een algemene } \\
\text { maatregel van bestuur } \\
\text { of ministeriële regeling }\end{array}$ & Afdeling 4.1 & Algemene regels \\
\hline Omgevingsvergunning & $\begin{array}{l}\text { Toestemming op } \\
\text { aanvraag tot het } \\
\text { verrichten van een of } \\
\text { meer activiteiten in de } \\
\text { fysieke leefomgeving }\end{array}$ & Afdeling 5.1 & $\begin{array}{l}\text { Regulering van } \\
\text { concrete activiteiten }\end{array}$ \\
\hline Projectbesluit & $\begin{array}{l}\text { Besluit voor het } \\
\text { uitvoeren van een } \\
\text { project en het in } \\
\text { werking hebben of in } \\
\text { stand houden daarvan }\end{array}$ & Afdeling 5.2 & $\begin{array}{l}\text { Regulering van } \\
\text { concrete projecten }\end{array}$ \\
\hline
\end{tabular}

De zes kerninstrumenten uit de Omgevingswet vervangen een diversiteit aan juridische rechtsfiguren uit de bestaande omgevingsrechtelijke wetgeving. Zo gaan de structuurvisie, het verkeer- en vervoerplan, het waterplan, de natuurvisie en het milieubeleidsplan op in de omgevingsvisie. Het 
projectbesluit biedt een uniforme procedure voor projecten met een publiek belang, zoals de aanleg van een weg of de verhoging van een dijk. Het projectbesluit vervangt het inpassingsplan uit de Wet ruimtelijke ordening, het tracébesluit uit de Tracéwet en het projectplan uit de Waterwet. Naast de kerninstrumenten bevat de Omgevingswet een aantal aanvullende instrumenten. Gedacht kan worden aan instructieregels, beoordelingsregels voor omgevingsvergunningen, regels over handhaving, schade, gedoogplichten enz.

\subsubsection{Consistent begripsgebruik}

Het is binnen het nieuwe wettelijke stelsel van cruciaal belang dat begrippen op een consistente wijze worden gebruikt. Dit geldt zeker voor zogenoemde kernbegrippen: begrippen die binnen het stelsel een centrale plaats innemen. Ieder kernbegrip heeft een eigen, unieke betekenis. Kernbegrippen vormen de bouwstenen van het stelsel. Deze begrippen zijn in de Omgevingswet vaak bewust niet gedefinieerd, bijvoorbeeld omdat ze een dynamisch karakter hebben, maar ze worden wel steeds in een vaste betekenis of context gebruikt.

Belangrijke kernbegrippen in het stelsel van de Omgevingswet zijn: (onderdelen van) de fysieke leefomgeving, locaties, functies en activiteiten. Het is voor de inzichtelijkheid van het stelsel en voor het vermijden van fouten bij de toepassing ervan van groot belang dat op een en dezelfde wijze gebruik wordt gemaakt van, en onderscheid wordt gemaakt tussen: onderdelen van de fysieke leefomgeving, zoals bouwwerken, infrastructuur, water, bodem en cultureel erfgoed, de geometrisch te begrenzen locaties waar deze onderdelen zich bevinden, de functie (dat wil zeggen het gebruiksdoel of de status) van een onderdeel van de fysieke leefomgeving op een bepaalde locatie, en activiteiten met mogelijke gevolgen voor de fysieke leefomgeving.

Het is belangrijk dat deze begrippen niet alleen in de regelgeving op centraal niveau, maar ook in de decentrale regels op het terrein van het omgevingsrecht en bij de toepassing daarvan consequent worden gebruikt. Als kernbegrippen niet consequent worden gebruikt, roept dit meteen vragen op over de inhoud en werking van het nieuwe stelsel. Ook is het zaak dat voor kernbegrippen geen synoniemen worden gebruikt. Daarom worden bijvoorbeeld activiteiten niet (ook) aangeduid als handelingen of werkzaamheden, en worden geen andere termen, zoals normen of kwaliteitseisen, gebruikt wanneer omgevingswaarden in de zin van de Omgevingswet worden bedoeld. Omgevingswaarden zijn als zodanig aangeduide doelstellingen voor de fysieke leefomgeving die in het stelsel van de Omgevingswet een specifieke juridische betekenis hebben. ${ }^{44}$ Dit betekent ook dat jurisprudentie over bestaande begrippen niet automatisch onder de Omgevingswet van toepassing blijft. De bestaande jurisprudentie zal in het licht van het nieuwe stelsel beoordeeld moeten worden. Dat geldt bijvoorbeeld voor begrippen als 'een goede ruimtelijke ordening' of 'bestemming' die in het nieuwe stelsel opgaan in bredere begrippen als 'een evenwichtige toedeling van functies aan locaties' en 'functie'.

Verder kenmerkt de nieuwe omgevingsrechtelijke wetgeving zich door een eenvoudiger taalgebruik vergeleken met de huidige wetgeving. De huidige wetgeving bevat nog vaak lastig leesbare bepalingen. Dit komt onder meer door het gebruik van ingewikkelde woorden en formuleringen. Een helder en modern(er) taalgebruik bevordert de toegankelijkheid van een wettelijk 


\subsection{Toepassingsgebied van de Omgevingswet}

\subsubsection{Fysieke leefomgeving}

Het toepassingsgebied van de Omgevingswet is geregeld in hoofdstuk 1 (Algemene bepalingen). Voor het toepassingsgebied zijn twee elementen van wezenlijk belang: de Omgevingswet gaat over de fysieke leefomgeving en over activiteiten die gevolgen hebben of kunnen hebben voor de fysieke leefomgeving (artikel 1.2, eerste lid, Ow). Bepalingen van de Omgevingswet en de daarop gebaseerde uitvoeringsregelgeving moeten binnen die reikwijdte blijven. Hetzelfde geldt voor de toepassing van de Omgevingswet door bestuursorganen van gemeenten, waterschappen, provincies en het Rijk. Denk aan de vaststelling van een omgevingsplan of een waterschapsverordening.

De Omgevingswet bevat geen begripsomschrijving van fysieke leefomgeving. Dit houdt verband met het brede en dynamische karakter van dit begrip. Veel van de huidige wetten op het gebied van het omgevingsrecht hanteren vergelijkbare dynamische begrippen. Voorbeelden hiervan zijn de begrippen ruimtelijke ordening (Wet ruimtelijke ordening) en fysieke leefomgeving (Wet algemene bepalingen omgevingsrecht). Ook in die gevallen bevat de wet geen begripsomschrijving.

Wel bevat de Omgevingswet een opsomming van onderdelen die in ieder geval deel uitmaken van de fysieke leefomgeving. Deze nadere duiding van het begrip fysieke leefomgeving is opgenomen in artikel 1.2, tweede lid, van de Omgevingswet.

Artikel 1.2 (fysieke leefomgeving)

2. De fysieke leefomgeving omvat in ieder geval:

a. bouwwerken,

b. infrastructuur,

c. watersystemen,

d. water,

e. bodem,

f. lucht,

g. landschappen,

h. natuur,

i. cultureel erfgoed,

j. werelderfgoed.

Deze inhoudelijke kleuring geeft de gebruiker een indicatie van de reikwijdte 
van de wet. Ook geeft deze opsomming houvast en structuur. Zo keren de genoemde onderdelen van de fysieke leefomgeving terug in de hoofdstuk-en paragraafindeling van de op de Omgevingswet gebaseerde uitvoeringsregelgeving. Het gaat bij de fysieke leefomgeving dus zowel om de natuurlijke omgeving (water, bodem, lucht, natuur) als om elementen die de mens daarin heeft aangebracht, zoals bouwwerken, wegen en spoorwegen.

De mens als zodanig is geen onderdeel van de fysieke leefomgeving. Via de uitbreidende bepaling van artikel 1.2, vierde lid, van de Omgevingswet kunnen de gevolgen voor de mens onder omstandigheden echter wel worden meegenomen.

\section{Artikel 1.2 (fysieke leefomgeving)}

4. Als gevolgen voor de fysieke leefomgeving worden ook aangemerkt gevolgen voor de mens, voor zover deze wordt of kan worden beïnvloed door of via onderdelen van de fysieke leefomgeving. ${ }^{46}$

Wat de Omgevingswet echter niet regelt, zijn directe betrekkingen tussen mensen. Steeds is de fysieke leefomgeving het medium waarlangs activiteiten van de een gevolgen hebben voor de ander. Dit betekent bijvoorbeeld dat de negatieve gevolgen van blootstelling van mensen aan luchtverontreiniging door het verkeer wel onder het toepassingsgebied van de Omgevingswet vallen, maar regels over gevaarlijk of verkeershinder veroorzakend verkeersgedrag niet. ${ }^{47} \mathrm{In}$ dat laatste geval ontbreekt de link met de fysieke leefomgeving.

\subsubsection{Activiteiten met gevolgen voor de fysieke leefomgeving}

Het tweede bepalende element voor het toepassingsgebied van de Omgevingswet, naast het begrip fysieke leefomgeving, betreft activiteiten die gevolgen hebben of kunnen hebben voor de fysieke leefomgeving (artikel 1.2, eerste lid, Ow). Op deze plaats in de wet, in hoofdstuk 1, gaat het om een nog niet nader afgebakende categorie activiteiten. Vereist is alleen dat de activiteit nadelige gevolgen, of mogelijke nadelige gevolgen, heeft voor de fysieke leefomgeving. In die brede betekenis wordt het begrip activiteit bijvoorbeeld gebruikt bij de algemene zorgplicht (artikel 1.7 Ow). Daarnaast bevat artikel 1.7a, eerste lid, van de Omgevingswet een strafrechtelijk handhaafbaar verbod om een activiteit te verrichten of na te laten als daardoor aanzienlijke nadelige gevolgen voor de fysieke leefomgeving ontstaan of dreigen te ontstaan. ${ }^{48}$

\footnotetext{
In het Omgevingsbesluit ${ }^{49}$ zullen gevallen worden aangewezen waarin dit verbod van toepassing is. Artikel 1.7a van de Omgevingswet strekt mede ter implementatie van de richtlijn milieustrafrecht. ${ }^{\mathbf{5 0}}$ Het gaat bijvoorbeeld om gevallen die nu onder de zorgplicht van artikel 13 van de Wet bodembescherming vallen, waaronder het verontreinigen of aantasten van de fysieke leefomgeving. Artikel 1.7a van de Omgevingswet vervult de functie van vangnet voor activiteiten die niet op grond van andere hoofdstukken van de Omgevingswet specifiek geregeld zijn (artikel 1.8, tweede lid, Ow). ${ }^{\mathbf{5 1}}$ Voor strafrechtelijke handhaving moet sprake zijn van opzet of ten minste schuld. Artikel $1.7 \mathrm{a}$ is geen zorgplicht, omdat deze bepaling geen algemeen geformuleerde zorgverplichting bevat die de normadressaat ruimte laat voor meerdere gedragsalternatieven.
}

In volgende hoofdstukken van de Omgevingswet en in de 
uitvoeringsregelgeving vindt vervolgens een nadere trechtering plaats: regels gelden dan alleen voor bepaalde activiteiten. Zo bevat artikel 4.3, eerste lid, van de Omgevingswet de opdracht om bij AMvB regels te stellen over, onder meer, milieubelastende activiteiten, bouwactiviteiten en mijnbouwlocatieactiviteiten. $\mathbf{5 2}^{2}$

Van de in artikel 4.3 van de Omgevingswet genoemde activiteiten zijn in de begrippenlijst in de bijlage bij de wet begripsomschrijvingen opgenomen. Zo is een bouwactiviteit gedefinieerd als een activiteit inhoudende het bouwen van een bouwwerk. Die definitie moet worden gelezen in samenhang met de definitie van bouwen (plaatsen, geheel of gedeeltelijk oprichten, vernieuwen, veranderen of vergroten) en bouwwerk (een constructie van enige omvang van hout, steen, metaal of ander materiaal, die op de plaats van bestemming hetzij direct of indirect met de grond verbonden is, hetzij direct of indirect steun vindt in of op de grond, bedoeld om ter plaatse te functioneren, met inbegrip van de daarvan deel uitmakende bouwwerkgebonden installaties).

Een vergelijkbare trechtering is te vinden bij het aanwijzen van vergunningplichtige activiteiten op grond van artikel 5.1 van de Omgevingswet. 53 Het gaat daarbij onder andere om milieubelastende activiteiten, bouwactiviteiten en mijnbouwlocatieactiviteiten. Bij algemene maatregel van bestuur op grond van artikel 5.1 van de Omgevingswet worden vervolgens vergunningvrije of vergunningplichtige gevallen aangewezen.

Die aanwijzing gebeurt in het Besluit activiteiten leefomgeving en het Besluit bouwwerken leefomgeving. De vergunningplicht geldt veelal voor de zwaardere gevallen, bezien vanuit de invalshoek van mogelijke gevolgen voor de fysieke leefomgeving, waarvoor een voorafgaande toestemming van de overheid is vereist. Deze vergunningplicht kan voortvloeien uit Europese of internationale regelgeving, maar bijvoorbeeld ook zijn ingesteld met het oog op het voldoen aan omgevingswaarden of het bereiken van andere doelstellingen voor de fysieke leefomgeving. De vergunningplicht kan bijvoorbeeld worden gekoppeld aan een drempel voor de productiecapaciteit of het opgesteld vermogen (bij milieubelastende activiteiten). De lichtere gevallen vallen dan onder algemene rijksregels of blijven, althans vanuit het Rijk, ongeregeld.

\footnotetext{
Afbakening tussen centrale en decentrale regels over activiteiten Onder activiteiten met (mogelijke) gevolgen voor de fysieke leefomgeving valt een breed scala aan activiteiten met grote verschillen in aard en omvang van de gevolgen. Bij milieubelastende activiteiten kan het enerzijds gaan om bijvoorbeeld een bedrijf in de metaalindustrie of een groot glastuinbouwbedrijf, anderzijds om een sportvereniging waar de nadelige gevolgen voor het milieu vooral zitten in lokale hinder (geluid, lichtinstallatie) of om lozing van afvalwater door particuliere huishoudens in het gemeentelijke rioolstelsel. Algemene rijksregels en door het Rijk ingestelde vergunningplichten zijn bij uitstek geschikt om locatieonafhankelijke preventieve maatregelen en beste beschikbare technieken vast te leggen. In geval van algemene regels kan eventuele afstemming op de lokale situatie plaatsvinden via maatwerkregels of -voorschriften (paragraaf 4.1.2 Ow). Voor de activiteiten en effecten waarvoor de regels in grote mate afhankelijk zijn van de lokale situatie en die dus ook lokaal verschillen is het minder doelmatig en doeltreffend om rijksregels met maatwerkmogelijkheden te stellen. Gelet op het uitgangspunt 'decentraal, tenzij' heeft de regering ervoor
} 
gekozen om in die gevallen de regels primair in het omgevingsplan en de waterschapsverordening te laten stellen. ${ }^{54}$ Hoe deze bevoegdheden worden uitgeoefend, is primair aan de lokale democratie.

Ter illustratie wordt gewezen op de verdeling die is aangebracht bij milieubelastende activiteiten. Op rijksniveau worden algemene regels gesteld voor onder meer de industrie en de agrarische sector en voor een aantal milieubelastende activiteiten die bij veel bedrijven en soms ook bij huishoudens voorkomen, zoals bodemenergiesystemen, windturbines en het opslaan van gevaarlijke stoffen. Niet door het Rijk gereguleerde milieubelastende activiteiten behoren tot het domein van de gemeente of de provincie. Voorbeelden daarvan zijn hotels, restaurants, muziektheaters, sportfaciliteiten en supermarkten. Tot slot kan worden gedacht aan bepaalde lozingsactiviteiten in de regionale wateren, die niet langer door het Rijk maar door het waterschap worden geregeld.

De in deze paragraaf bedoelde regels over activiteiten betreffen de meest voorkomende situaties. Daarnaast bevat de Omgevingswet bijzondere regels over activiteiten. Voorbeelden hiervan zijn hoofdstuk 19 (Bevoegdheden in bijzondere omstandigheden), waarin onder meer regels zijn opgenomen over ongewone voorvallen, hoofdstuk 10 (Gedoogplichten) en de experimenteerbepaling van artikel 23.3.

\subsubsection{Verhouding tot andere wetgeving}

De Omgevingswet treedt terug als een andere wet op het gebied van de fysieke leefomgeving voorziet in een uitputtende regeling. Deze lex specialis-regel is vastgelegd in artikel 1.4 van de Omgevingswet.

Binnen het brede toepassingsgebied van de Omgevingswet zullen ook andere wetten blijven bestaan. Voor de materiële betekenis van artikel 1.4 van de Omgevingswet is van belang dat de Invoeringswet en de aanvullingswetten voorzien in de intrekking van diverse omgevingsrechtelijke wetten of de onderdelen daarvan die opgaan in de Omgevingswet. Bij inwerkingtreding van de Omgevingswet (zie de paragrafen 1.5.1 en 1.5.2) blijven er echter wetten gelden die bepaalde aspecten van de fysieke leefomgeving reguleren of die specifieke belangen borgen. ${ }^{55}$ Voorbeelden zijn de Meststoffenwet en de Kernenergiewet. De Omgevingswet treedt terug als een dergelijke specifieke wet voorziet in een uitputtende regeling.

\subsection{Doelen van de Omgevingswet}

\subsubsection{Maatschappelijke doelen van de Omgevingswet}

In hoofdstuk 1 van de Omgevingswet zijn de zogenoemde maatschappelijke doelen van de wet aangeduid. Deze doelen zijn richtinggevend bij de uitvoering van de Omgevingswet door bestuursorganen waaraan taken of bevoegdheden zijn toegedeeld. De doelen geven ook sturing aan het handelen van de wetgever zelf, overal daar waar de Omgevingswet regelgevende bevoegdheden delegeert aan de regering (AMvB) of aan een minister (ministeriële regeling). De maatschappelijke doelen zijn neergelegd in artikel 1.3 van de Omgevingswet.

Artikel 1.3 (maatschappelijke doelen van de wet)

Deze wet is, met het oog op duurzame ontwikkeling, de bewoonbaarheid van 
het land en de bescherming en verbetering van het leefmilieu, gericht op het in onderlinge samenhang:

a. bereiken en in stand houden van een veilige en gezonde fysieke leefomgeving en een goede omgevingskwaliteit, ook vanwege de intrinsieke waarde van de natuur, ${ }^{56}$ en

b. doelmatig beheren, gebruiken en ontwikkelen van de fysieke leefomgeving ter vervulling van maatschappelijke behoeften.

De formulering van artikel 1.3 van de Omgevingswet sluit aan bij wat in de memorie van toelichting het motto van de wet wordt genoemd: ruimte voor ontwikkeling, waarborgen voor kwaliteit. Artikel 1.3 sluit ook aan bij het opschrift van de Omgevingswet, waarin is aangegeven dat de wet regels bevat over het beschermen en benutten van de fysieke leefomgeving. Waar in de Omgevingswet kortheidshalve wordt gesproken over 'de doelen van de wet', worden de maatschappelijke doelen van artikel 1.3 bedoeld. ${ }^{57}$ In artikel 1.3 zijn verschillende elementen te onderscheiden.

Het doel 'het bereiken en in stand houden van een veilige en gezonde fysieke leefomgeving en een goede omgevingskwaliteit (..)' (onderdeel a) benadrukt de opdracht tot het waarborgen van de kwaliteit van de fysieke leefomgeving. Dit ziet op de beschermende kant van het omgevingsrecht. De Omgevingswet is onder meer gericht op het beschermen van het milieu, het beschermen van de gezondheid en het waarborgen van de veiligheid. Veiligheid moet hier breed worden opgevat: het gaat niet alleen om externe veiligheid, $\mathbf{5 8}$ maar bijvoorbeeld ook om de veiligheid van primaire waterkeringen en de constructieve veiligheid van bouwwerken. Onder het beschermen van het milieu wordt verstaan: het beschermen en verbeteren van het milieu. ${ }^{\mathbf{5 9}}$ Omdat de samenleving meer verwacht van de fysieke leefomgeving dan alleen de hiervoor genoemde aspecten, is ook het element 'een goede omgevingskwaliteit' opgenomen in onderdeel a van artikel 1.3 van de Omgevingswet. Dit ziet bijvoorbeeld op het behoud van cultureel erfgoed, natuurbescherming en het beschermen van landschappelijke en stedenbouwkundige waarden. ${ }^{\mathbf{6 0}}$ Daarbij is, evenals in de Wet natuurbescherming het geval was, expliciet de intrinsieke waarde van de natuur tot uitdrukking gebracht.

Het doel 'het beheren, gebruiken en ontwikkelen van de fysieke leefomgeving ter vervulling van maatschappelijke behoeften' (onderdeel b) brengt tot uitdrukking dat de fysieke leefomgeving daarnaast door de mens kan worden benut voor maatschappelijke opgaven. Deze opgaven kunnen bijvoorbeeld liggen op het vlak van industrie, landbouw, verkeer en wonen. De drie werkwoorden in onderdeel b duiden op de verschillende wijzen waarop de mens handelt in de fysieke leefomgeving. Beheren kan bijvoorbeeld zien op infrastructuur en watersystemen (zoals dijken en rivieren), gebruiken op bijvoorbeeld watersystemen (denk aan het onttrekken van water) en de bodem (denk aan ontgrondingen) en ontwikkelen op bijvoorbeeld het bouwen van bouwwerken. De term doelmatig benadrukt dat de beschikbare gebruiksruimte zo efficiënt mogelijk moet worden verdeeld over de verschillende maatschappelijke behoeften. In het nieuwe stelsel van omgevingsrecht vervult het omgevingsplan een spilfunctie bij het sturen op gebruiksruimte (de binnen een gebied aanwezige juridische ruimte voor activiteiten binnen de in de regelgeving gestelde kaders). Inhoudelijke regels op grond van de 
Omgevingswet hebben voornamelijk betrekking op onderdeel a van artikel 1.3.

De aanhef van artikel 1.3 van de Omgevingswet verwijst naar artikel 21 van de Grondwet. De regels van de Omgevingswet zijn mede gericht op de zorg voor de bewoonbaarheid van het land en de bescherming en verbetering van het leefmilieu. De aanhef bevat nog twee andere belangrijke elementen: duurzame ontwikkeling en een samenhangende benadering van de fysieke leefomgeving. Met de verwijzing naar duurzame ontwikkeling wordt benadrukt dat bij de toepassing van de Omgevingswet niet alleen de behoeften van de huidige generatie leidend zijn, maar dat ook rekening moet worden gehouden met de behoeften van toekomstige generaties. ${ }^{\mathbf{6 1}}$ Het bewerkstelligen van een meer samenhangende benadering van de fysieke leefomgeving in beleid, besluitvorming en regelgeving is een van de verbeterdoelen van de stelselherziening van het omgevingsrecht (zie paragraaf 1.3). Daarbij aansluitend bepaalt artikel 1.3 van de Omgevingswet dat de maatschappelijke doelen van de wet in onderlinge samenhang moeten worden bezien. Complexe problemen en maatschappelijke opgaven in de fysieke leefomgeving vergen een meer integrale aanpak; een sectorale benadering is daarvoor niet altijd doelmatig en doeltreffend. De samenhangende benadering komt vooral tot uitdrukking in de fase van beleidsvorming, bijvoorbeeld bij het opstellen van een omgevingsvisie (afdeling 3.1 Ow). Dit is een instrument waarin het integrale beleid voor de fysieke leefomgeving (van gemeente, provincie of Rijk) wordt vastgelegd. Hoewel artikel 1.3 een brede doelomschrijving van de Omgevingswet geeft, zorgen de doelen ook voor een begrenzing. Onderwerpen als arbeidsomstandigheden, dierenwelzijn en openbare orde vallen niet onder de reikwijdte van de wet. ${ }^{62}$

Het is van belang dat bij de uitoefening van door de Omgevingswet toegekende taken en bevoegdheden een goede balans wordt bereikt tussen bovengenoemde maatschappelijke doelen. Dit geldt voor bevoegdheden op alle bestuursniveaus en voor alle soorten bevoegdheden, zowel regelgevende bevoegdheden als de bevoegdheid tot besluitvorming in concrete gevallen (omgevingsvergunning, projectbesluit). Artikel 1.3 van de Omgevingswet, opgenomen in het inleidende hoofdstuk van de wet, doet zelf geen uitspraken over hoe de belangenafweging in concrete gevallen moet uitvallen. Het is aan de bevoegde bestuursorganen om bij de toepassing van de wet die balans te bewaken. Aan de memorie van toelichting is dit citaat ontleend:

'De twee doelstellingen tonen het spanningsveld van het omgevingsbeleid. Maximale bescherming leidt tot onvervulde maatschappelijke wensen.

Maximale ontwikkeling leidt tot een onleefbaar land. De wet is een belangrijk instrument bij het bewaren van de balans. ${ }^{, 63}$

In veel gevallen wordt artikel 1.3 van de Omgevingswet ingekleurd doordat elders in de Omgevingswet, of in de daarop gebaseerde uitvoeringsregelgeving, specifieke kaders voor de uitoefening van taken en bevoegdheden zijn gegeven. Hierop wordt ingegaan in paragraaf 2.3.2.

\subsubsection{Specifieke afwegingskaders}

Zoals in paragraaf 2.3.1 is beschreven, geeft artikel 1.3 van de Omgevingswet (maatschappelijke doelen) richting aan de uitvoering en toepassing van de wet. Een belangrijke beperking is dat als elders in de Omgevingswet of in de daarop 
gebaseerde uitvoeringsregelgeving specifieke kaders voor de uitoefening van taken en bevoegdheden zijn gegeven, die kaders voorgaan. Die meer specifieke kaders zijn dan leidend. De specifieke kaders worden geacht een invulling te zijn van het algemene artikel 1.3. Deze systematiek is af te leiden uit artikel 2.1, eerste tot en met derde lid, van de Omgevingswet.

\section{Artikel 2.1 (uitoefening taken en bevoegdheden) ${ }^{64}$}

1. Een bestuursorgaan van een gemeente, een provincie of het Rijk of, met inachtneming van de Waterschapswet, van een waterschap oefent zijn taken en bevoegdheden op grond van deze wet uit met het oog op de doelen van de wet, tenzij daarover specifieke regels zijn gesteld.

2. Het bestuursorgaan houdt daarbij rekening met de samenhang van de relevante onderdelen en aspecten van de fysieke leefomgeving en van de rechtstreeks daarbij betrokken belangen.

3. Bij de op grond van deze wet gestelde regels kan de toepassing van het eerste en tweede lid worden uitgewerkt of begrensd. Deze uitwerking of begrenzing kan in ieder geval betrekking hebben op:

a. het waarborgen van de veiligheid,

b. het beschermen van de gezondheid,

c. het beschermen van het milieu,

d. het duurzaam veiligstellen van de openbare drinkwatervoorziening,

e. het beschermen van landschappelijke of stedenbouwkundige waarden,

f. het behoud van cultureel erfgoed,

g. het behoud van de uitzonderlijke universele waarde van werelderfgoed,

h. de natuurbescherming,

i. het tegengaan van klimaatverandering,

j. de kwaliteit van bouwwerken,

k. een evenwichtige toedeling van functies aan locaties,

I. het behoeden van de staat en werking van infrastructuur voor nadelige gevolgen van activiteiten,

$m$. het beheer van infrastructuur,

$\mathrm{n}$. het beheer van watersystemen, 
o. het beheer van geobiologische en geothermische systemen en ecosystemen,

p. het beheer van natuurlijke hulpbronnen,

q. het beheer van natuurgebieden,

r. het gebruik van bouwwerken,

s. het bevorderen van de toegankelijkheid van de openbare buitenruimte voor personen.

4. Onverminderd het derde lid wordt bij de evenwichtige toedeling van functies aan locaties in ieder geval rekening gehouden met het belang van het beschermen van de gezondheid.

Een voorbeeld van een dergelijke verbijzondering is te vinden in artikel 4.23, eerste lid, van de Omgevingswet, de delegatiegrondslag voor algemene rijksregels over wateractiviteiten. Die regels worden gesteld met het oog op onder meer het voorkomen en waar nodig beperken van overstromingen, wateroverlast en waterschaarste en het beschermen en verbeteren van de chemische en ecologische kwaliteit van watersystemen. Vergelijkbare concretiseringen zijn te vinden bij de beoordelingsregels voor de omgevingsvergunning (paragraaf 5.1.3 Ow) en in de delegatiegrondslagen voor instructieregels voor omgevingsplannen (afdeling 2.5 Ow). Zo strekken de bij $\mathrm{AMvB}$ (het Besluit kwaliteit leefomgeving) te stellen beoordelingsregels voor een omgevingsvergunning voor een rijksmonumentenactiviteit tot het behoud van cultureel erfgoed. Daarbinnen gaat het bijvoorbeeld om het voorkomen van ontsiering, beschadiging, sloop of verplaatsing van monumenten en het conserveren en in stand houden van archeologische monumenten (artikel 5.22 Ow). Waar bij de besluitvorming over concrete activiteiten de bestaande specifieke afwegingskaders goed werken, zijn deze onder de Omgevingswet veelal gehandhaafd en dus niet vervangen door 'de doelen van de wet'. Omwille van de herkenbaarheid worden deze specifieke doelen of belangen in de Omgevingswet en de uitvoeringsregelgeving steeds ingeleid met de zinsnede 'met het oog op'. Die begrenzen daarmee dus het afwegingskader voor de te nemen besluiten.

\subsection{Uitoefening van taken en bevoegdheden met het oog op de doelen van de wet ${ }^{65}$}

\subsubsection{Doelbinding}

Bestuursorganen hebben in het bestuursrecht geen algemene bevoegdheid om het algemeen belang te behartigen, maar uitsluitend speciale - doelgebonden bevoegdheden. Het bestuursorgaan zal dus steeds moeten nagaan met welk doel een bevoegdheid is toegekend. Het doel dat de wetgever voor ogen heeft gehad, kan in algemene zin blijken uit het betrokken wettelijk voorschrift, uit de considerans van de wet of uit de parlementaire behandeling. ${ }^{66}$ In de Omgevingswet en de daarop gebaseerde uitvoeringsregelgeving is omwille van de rechtszekerheid waar relevant in de wettelijke bepalingen zelf het achterliggende oogmerk aangegeven. Zoals in de paragrafen 2.3.1 en 2.3.2 is beschreven, kan binnen de nieuwe omgevingsrechtelijke wetgeving 
onderscheid worden gemaakt tussen de algemene maatschappelijke doelen van de Omgevingswet en specifieke doelen en belangen.

In artikel 1.3 van de Omgevingswet zijn de maatschappelijke doelen van die wet in algemene zin benoemd. Deze twee maatschappelijke doelen zijn, kort gezegd, het beschermen en het benutten van de fysieke leefomgeving (zie paragraaf 2.3.1). In het vervolg van de wet, in de uitvoeringsregelgeving of bij de toepassing van de Omgevingswet worden deze doelen geconcretiseerd voor bepaalde onderdelen van de fysieke leefomgeving, bijvoorbeeld voor water of lucht, of in verband met bepaalde maatschappelijke opgaven, zoals klimaatadaptatie of energietransitie. Deze concretiseringen kunnen zijn aangegeven in een omgevingsvisie of een programma.

Een voorbeeld van een bepaling waarin de maatschappelijke doelen van de Omgevingswet het kader vormen voor de uitoefening van bevoegdheden is artikel 2.9 van de Omgevingswet. Artikel 2.9, eerste lid, bepaalt dat als omgevingswaarden worden vastgesteld, dit gebeurt met het oog op de doelen van de wet. De bestuurlijke afweging die dan op grond van artikel 1.3 van de Omgevingswet moet plaatsvinden, heeft onder andere betrekking op de hoogte van de norm die als omgevingswaarde wordt vastgelegd. Denk aan de hoogte van een norm voor luchtkwaliteit. Dit betreft primair een politiek-bestuurlijke afweging en komt tot uitdrukking in een $\mathrm{AMvB}$, omgevingsverordening of omgevingsplan. Ook als er in een artikel geen expliciete verwijzing naar de doelen van de wet is opgenomen of als er geen specifieke regels zijn gesteld, vormt artikel 1.3 van de Omgevingswet het algemene kader voor de uitoefening van taken of bevoegdheden. Dit volgt uit artikel 2.1, eerste lid, van de Omgevingswet. Als er wel specifieke regels zijn gesteld, gaat dat specifiekere kader (lees: het specifieke doel of belang) voor (zie paragraaf 2.3.2).

\subsubsection{Doelstellingen voor de fysieke leefomgeving}

De Omgevingswet bepaalt op een aantal plaatsen dat bestuursorganen bevoegdheden of taken kunnen uitoefenen 'om te voldoen aan bij algemene maatregel van bestuur vastgestelde omgevingswaarden of voor het bereiken van andere doelstellingen voor de fysieke leefomgeving'. Dit gebeurt onder meer bij de grondslagen voor instructieregels in hoofdstuk 2 van de Omgevingswet. Zie bijvoorbeeld artikel 2.24, eerste lid, van de Omgevingswet. Het begrip 'doelstellingen voor de fysieke leefomgeving' duidt op beleidsdoelen voor (onderdelen van) de fysieke leefomgeving. Het gaat daarbij om concrete doelstellingen, bijvoorbeeld voor de kwaliteit van de bodem of het oppervlaktewater. Deze doelstellingen geven voor een of meer onderwerpen concreet invulling aan de maatschappelijke doelen van de Omgevingswet als bedoeld in artikel 1.3 of meer specifieke doelen en belangen waarvan de belangrijkste zijn aangegeven in artikel 2.1, derde lid, van de Omgevingswet.

Het overkoepelende begrip 'doelstellingen voor de fysieke leefomgeving' omvat naast omgevingswaarden ook andere soorten doelstellingen. Het gaat daarbij om doelstellingen die worden geformuleerd door bestuursorganen die zijn belast met taken en bevoegdheden op het gebied van de fysieke leefomgeving. Dit kunnen heel diverse doelstellingen zijn voor een of meer onderdelen van de fysieke leefomgeving. Bijvoorbeeld doelstellingen voor de kwaliteit van het oppervlaktewater (denk aan kwaliteitsdoelstellingen neergelegd in een waterprogramma) of voor de ontwikkeling van woningbouwlocaties 
(bijvoorbeeld de verduurzaming van 7 miljoen woningen als bedoeld in het klimaatakkoord). Doelstellingen kunnen zowel kwalitatief als kwantitatief zijn geformuleerd. Deze 'andere doelstellingen voor de fysieke leefomgeving' kunnen blijken uit schriftelijke openbare documenten van overheden, bijvoorbeeld een omgevingsvisie, een programma of een ander beleidsdocument. Die doelstellingen kunnen worden vertaald in juridisch bindende regels, bijvoorbeeld in beoordelingsregels voor omgevingsvergunningen of in algemene regels. Er is dan geen sprake van een omgevingswaarde met de daaraan op grond van de Omgevingswet verbonden rechtsgevolgen, maar er wordt op andere wijze in voorzien dat de doelstelling doorwerkt in de uitoefening van taken of bevoegdheden of is vertaald in direct werkende regels voor burgers en bedrijven. Dit geldt bijvoorbeeld voor de onderwerpen externe veiligheid, geur en cultureel erfgoed.

\section{Noten}

* Deze bijdrage is op persoonlijke titel geschreven. De tekst van deze bijdrage is afgesloten op 10 oktober 2018.

1 Het Besluit kwaliteit leefomgeving, het Besluit activiteiten leefomgeving, het Besluit bouwwerken leefomgeving en het Omgevingsbesluit.

2 De inhoud van deze bijdrage is deels ontleend aan: H.A. Oldenziel en H.W. de Vos, Systeem en kerninstrumenten van de Omgevingswet, Wolters Kluwer, 2018, p. 1-29.

3 Kamerstukken II 2009/10, 32123 XI, nr. 16.

4 Kamerstukken II 2010/11, 32417, nr. 15; Kamerstukken II 2012/13, 33410, nr. 15; Kamerstukken II 2017/18, 34700, nr. 34 (bijlage).

5 Aan dit vierde verbeterdoel wordt onder meer invulling gegeven door het samenvoegen van (thans sectoraal geregelde) besluitvormingsprocessen en door transparantere besluitvorming over complexe projecten met vroegtijdige publiekparticipatie (Kamerstukken II 2013/14, 33962, nr. 3, p. 32-33).

6 Kamerstukken II 2013/14, 33962, nr. 3, p. 4 en 25.

7 Kamerstukken II 2013/14, 33962, nr. 4, p. 5.

8 Kamerstukken II 2010/11, 31953, nr. 39.

9 Ministerie van Infrastructuur en Milieu: Bezinning op het omgevingsrecht: essays over de toekomst van het omgevingsrecht, 2010.

10 Kamerstukken II 2010/11, 31953, nrs. 39 en 40.

11 Kamerstukken II 2011/12, 33118, nr. 3, bijlage IV.

12 Kamerstukken II 2011/12, 33118, nr. 3.

13 Kamerstukken II 2013/14, 33962, nr. 4. 
14 Kamerstukken II 2013/14, 33962, nrs. 1, 2 en 3.

15 Bijlage bij Kamerstukken II 2014/15, 33962, nr. 14.

16 In de Tweede Kamer is het wetsvoorstel Omgevingswet met 144 van de 150 stemmen aangenomen. In de Eerste Kamer met 69 van de 75 stemmen.

17 Stb. 2016, 156.

18 Stb. 2018, nrs. 290 tot en met 293.

19 Voorlichting van 25 januari 2012 met betrekking tot de herziening van het omgevingsrecht, W14.11.0341/IV (bijlage bij Kamerstukken II, 33118, nr. 3, p. 37).

20 Kamerstukken II 2013/14, 33962, nr. 3, p. 316-326.

21 Kamerstukken II 2013/14, 33 962, nr. 3, p. 326.

22 Stb. 2018, nr. 290, p. 73.

23 Maatwerk betreft de mogelijkheid tot invulling, aanvulling of afwijking van algemene rijksregels. Maatwerk kent twee varianten: maatwerkregels en maatwerkvoorschriften (artikelen 4.5 en 4.6 Ow).

24 Een gelijkwaardige maatregel is een alternatief voor een voorgeschreven maatregel. Voorwaarde daarvoor is dat daarmee hetzelfde resultaat wordt bereikt (artikel $4.7 \mathrm{Ow}$ ).

25 Wet van 9 december 2015 tot wijziging van de Wet algemene bepalingen omgevingsrecht (verbetering vergunningverlening, toezicht en handhaving) (Stb. 2015, 521). Wet van 2 november 2016 tot wijziging van de Waterwet en enkele andere wetten (nieuwe normering primaire waterkeringen) (Stb. 2016, 431).

26 Wet van 25 januari 2017 tot wijziging van de Wet milieubeheer en de Crisisen herstelwet in verband met de uitvoering van Richtlijn 2014/52/EU van het Europees Parlement en de Raad van 16 april 2014 tot wijziging van Richtlijn 2011/92/EU betreffende de milieueffectbeoordeling van bepaalde openbare en particuliere projecten (PbEU 2014, L 124) (implementatie herziening merrichtlijn) (Stb. 2017, 30).

27 Dit zijn tijdelijke regels om te voorkomen dat een locatie minder geschikt wordt voor de verwezenlijking van de beoogde nieuwe functie of andere regels. Deze regels worden via een voorbereidingsbesluit in het omgevingsplan opgenomen.

28 Kamerstukken II 2017/18, 34864, nr. 2.

29 Kamerstukken II 2017/18, 34864, nr. 3, p. 5-9.

30

https://www.internetconsultatie.nl/aanvullingsbesluit_bodem_omgevingswet 
31 Wetsvoorstel Aanvullingswet natuur Omgevingswet, Kamerstukken II 2017/18, 34985, nr. 2.

32 Wetsvoorstel Aanvullingswet geluid Omgevingswet, Kamerstukken II 2018/19, 35 054, nr. 2.

33 Artikel 4.3, eerste lid, onder g, nader uitgewerkt in artikel 4.27 van de Omgevingswet. Daarnaast kunnen op grond van artikel 2.24 van de Omgevingswet instructieregels worden gesteld over de toepassing van maatwerk door het bevoegd gezag.

34 Dit wordt via de Invoeringswet geregeld in artikel 20.20 van de Omgevingswet.

35 De landelijke voorziening wordt via de Invoeringswet geregeld in artikel 20.21 van de Omgevingswet.

36 Kamerstukken II 2017/18, 34985, nr. 3, p. 50.

37 Kamerstukken II 2013/14, 33962, nr. 4.

38 Zie nader: C.D. Palm \& H.W. de Vos, 'De Tweede Kamerbehandeling van het wetsvoorstel Omgevingsrecht: de politieke waardering van de stelselherziening', Tijdschrift voor Omgevingsrecht 2015, afl. 3, p. 100.

39 Kamerstukken II 2017/18, 34864, nr. 4.

40 Paragraaf 3.2.4 Ow.

41 Meer gedetailleerde regels kunnen bij ministeriële regeling worden gesteld. In de Omgevingswet wordt hiervoor meestal als criterium gehanteerd dat het moet gaan om uitvoeringstechnische, administratieve of meet- of rekenvoorschriften. Zie bijvoorbeeld artikel 4.3, derde lid, van de Omgevingswet.

42 Een andere mogelijkheid is het verlenen van een omgevingsvergunning om af te wijken van het omgevingsplan (een omgevingsvergunning voor een omgevingsplanactiviteit).

43 De tabel is een bewerkte en aangevulde versie van tabel 1 uit de memorie van toelichting bij de Omgevingswet (Kamerstukken II 2013/14, 33962, nr. 3, p. 8).

44 Zie afdeling 2.3 Ow en paragraaf 2.4.2.

45 Zie hierover nader: J.H. Meijer, H.A. Oldenziel en H.W. de Vos, “The making of van de stelselherziening omgevingsrecht', in: Stelselherzieningen (preadviezen Vereniging voor Wetgeving en Wetgevingsbeleid 2016), Oisterwijk: Wolf Legal Publishers 2016, p. 66-71, en H.A. Oldenziel en H.W. de Vos, 'Toegankelijk wetgeven onder de Omgevingswet', Regelmaat 2018-1-2, p. 73-81.

46 Op grond van de Omgevingswet kunnen regels worden gesteld met het oog 
op het beschermen van de gezondheid (artikel 2.1, derde lid). Bij de evenwichtige toedeling van functies aan locaties in het omgevingsplan moet in ieder geval rekening worden gehouden met het belang van het beschermen van de gezondheid (artikel 2.1, vierde lid). Zie ook paragraaf 2.3.

47 Zoals regels als bedoeld in hoofdstuk II (Verkeersgedrag) van de Wegenverkeerswet 1994.

48 Zoals ingevoegd door de Invoeringswet.

$49 \mathrm{Na}$ wijziging door het Invoeringsbesluit.

50 Richtlijn 2008/99/EG van het Europees Parlement en de Raad van 19 november 2008 inzake de bescherming van het milieu door middel van het strafrecht ( $P b E U$ 2008, L 328/28).

51 Zoals ingevoegd door de Invoeringswet.

52 Na wijziging door de Invoeringswet.

53 Na wijziging door de Invoeringswet.

54 Nota van toelichting bij het Besluit activiteiten leefomgeving (Stb. 2018, 293), p. 562.

55 De bijlagen 1 en 2 bij de nota naar aanleiding van het verslag bij de Omgevingswet bevatten een uitgebreide beschrijving van de wetten die grotendeels in het nieuwe stelsel opgaan of waarvan (een beperkt aantal) onderdelen overgaan naar de Omgevingswet (Kamerstukken II 2014/15, 33962, nr. 12, p. 296-333).

56 Na wijziging door de Aanvullingswet natuur Omgevingswet.

57 Zie de definitie van 'doelen van de wet' in de begrippenlijst in de bijlage bij de Omgevingswet.

58 Externe veiligheid betreft het beleid gericht op het beperken van de kans op, en het effect van, een ernstig ongeval door activiteiten met gevaarlijke stoffen (nota van toelichting bij het Besluit externe veiligheid inrichtingen; Stb. 2004, 250, p. 18).

59 Zie de definitie van 'beschermen' in de begrippenlijst in de bijlage bij de Omgevingswet (na wijziging door de Invoeringswet).

6o Deze en andere belangen die in ieder geval onder artikel 1.3 van de Omgevingswet zijn te scharen, zijn af te leiden uit artikel 2.1, derde lid, van de Omgevingswet (uitoefening taken en bevoegdheden). Dat derde lid wordt overigens nog aangevuld via de Aanvullingswet natuur Omgevingswet.

61 Zie de begripsomschrijving van 'duurzame ontwikkeling' in de begrippenlijst in de bijlage bij de Omgevingswet. 
63 Kamerstukken II 2013/14, 33962, nr. 3, p. 63-64.

$64 \mathrm{Na}$ wijziging door de Invoeringswet en de Aanvullingswet natuur.

65 Deze paragraaf zal in het handboek een plaats krijgen in het hoofdstuk over taken en bevoegdheden.

66 L.J.A. Damen e.a., Bestuursrecht 1, tweede druk, Den Haag: Boom 2005, p. 58. Dat bevoegdheden met een speciaal doel (moeten) worden toegekend, volgt uit het specialiteitsbeginsel, als uitwerking van het legaliteitsbeginsel.

Deze bijdrage is op persoonlijke titel geschreven. De tekst van deze bijdrage is afgesloten op 10 oktober 2018.

(C) Boom juridisch 